\title{
Faujasit-Na a doprovodná zeolitová mineralizace z lokality Klučky u Polevska v Lužických horách (Česká republika)
}

\author{
Faujasit-Na and accompanying zeolite mineralization from the locality Klučky near \\ Polevsko in the Lužické hory Mts. (Czech Republic)
}

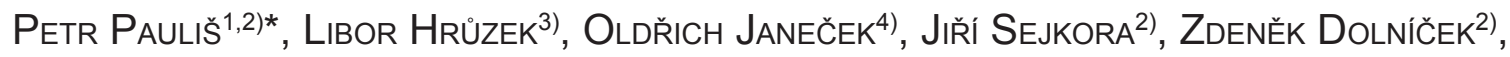 \\ Luboš VRtiška ${ }^{2)}$, Radana Malíkováa ${ }^{2)}$, OndŘej Pour ${ }^{5)}$ a Ferry Fediuk ${ }^{6)}$ \\ 1)Smíškova 564, 28401 Kutná Hora; *e-mail petr.paulis@post.cz \\ ${ }^{2)}$ Mineralogicko-petrologické oddělení, Národní muzeum, Cirkusová 1740, 19300 Praha 9 - Horní Počernice \\ 3)Pobřežní 1016, 47114 Kamenický Šenov \\ 4)Albrechtická 613, 43401 Most \\ 5)Česká geologická služba, Geologická 6, 15200 Praha 5 \\ ${ }^{6)} \mathrm{Na}$ Petřinách 1897, 16200 Praha 6
}

Pauliš P, Hrưzek L, Janeček O, Sejkora J, Dolniček Z, VRtiška L, Malíková R, Pour O, Fediuk F (2020) Faujasit-Na a doprovodná zeolitová mineralizace z lokality Klučky u Polevska v Lužických horách (Česká republika). Bull Mineral Petrolog 28(2): 417-436 ISSN 2570-7337

\begin{abstract}
Four new zeolite occurrences have been discovered in a forested, $3 \mathrm{~km}$ long ridge Klučky, composed of basaltic rocks and culminating in the $642 \mathrm{~m}$ high elevation of the same name NW of the Nový Bor town in the Lužické hory Mts. At the Wachstein locality, the first occurrence of the rare zeolite faujasite-Na in the Czech Republic was verified. It forms octahedral crystals up to $0.3 \mathrm{~mm}$ in size with common twins according to spinel law. The unit-cell parameter of faujasite-Na refined from the powder $X$-ray data is a 24.6775(9) $\AA$ and $V 15028.1(9) \AA^{3}$. Its chemical analyses correspond to the empirical formula $\left(\mathrm{Na}_{1.43} \mathrm{Ca}_{1.20} \mathrm{~K}_{0.44} \mathrm{Mg}_{0.16}\right)_{\Sigma 3.23}\left(\mathrm{Al}_{3.33} \mathrm{Si}_{8.36}\right) \mathrm{O}_{24} \cdot 15 \mathrm{H}_{2} \mathrm{O}$. Besides to phillipsite and chabazite, frequent offretite, characterised by its extraordinary morphological variety, is present in all described localities. The unit-cell parameters of offretite refined from the powder X-ray data are: a 13.311(6), c 7.5934(6) $\AA$ and $V 1165.2(5) \AA^{3}$ (Wachstein) and a 13.310(5), c 7.5886(5) $\AA$ and $V$ 1164.3(4) $\AA^{3}$ (Klučky - Stráň). Chemical analyses of offretite correspond to the empirical formula $\mathrm{K}_{2.02} \mathrm{Ca}_{1.31} \mathrm{Mg}_{0.32} \mathrm{Sr}_{0.09}\left(\mathrm{Al}_{5.42} \mathrm{Si}_{12.56}\right) \mathrm{O}_{36} \cdot 16 \mathrm{H}_{2} \mathrm{O}$ (Wachstein) and $\mathrm{Ca}_{1.48} \mathrm{~K}_{1.02} \mathrm{Mg}_{0.59} \mathrm{Na}_{0.10} \mathrm{Sr}_{0.09}\left(\mathrm{Al}_{5.56} \mathrm{Si}_{12.52}\right)$ $\mathrm{O}_{36} \cdot 16 \mathrm{H}_{2} \mathrm{O}$ (Klučky - Stráň).
\end{abstract}

Key words: faujasite-Na, offretite, phillipsite-K, phillipsite-Ca, chabazite-K, powder X-ray diffraction data, unit-cell parameters, chemical composition, Klučky, Polevsko, Lužické hory Mts., Czech Republic

Obdrženo 21. 10. 2020; prijiato 7. 12. 2020

\section{Úvod}

Mezi obcemi Prácheň u Kamenického Šenova (na západě), Polevsko a Arnultovice (na východě) probíhá ve směru ZJZ - VSV zalesněný, asi 3 km dlouhý vulkanický hřbet $s$ několika vyvýšeninami (obr. 1). Nejvyšší bod s kótou $642 \mathrm{~m}$ n. m. se nazývá Klučky. Celý hřeben, včetně dalších kót, z nichž některé mají i své názvy a jiné jsou bezejmenné, je pak souhrnně nazýván právě podle nejvyššího bodu - Klučky. Od jihozápadu se návrší mírně zvedá z mělkého sedla u Kamenického Šenova. Prvním výrazným bodem je kóta $631 \mathrm{~m}$ n. m., místo nazývané U Obrázku. V současné době je zde výrazná telekomunikační věž. Poté se ještě hřeben mírně zvedá ke své vrcholové kótě Klučky (642 m n. m.). Při této kótě, severním směrem, se nachází zaniklý dvouetážový kamenolom. $\mathrm{V}$ bazaltovém lomu jsou patrné minimálně dva lávové proudy. Vrchní proud, zastižený horním patrem lomu, je tvořen vertikálně orientovanými sloupy olivinického bazaltu. Zdejší sloupce vynikají svou dokonalou odlučností a zejména několikanásobně větši šířkou opro- ti známým sloupcům například z Panské skály. Poté, již ve své polovině, směrem na severovýchod, hřbet mírně klesá. V mělkém sedle, asi 500 m od vrcholu, se nachází zajímavý bazaltový výchoz. $V$ těchto místech stojí starý trojhranný patník s letopočtem 1831 označující trojmezí trrí panství, kamenického, sloupského a novozámeckého. Pracovně jsme toto místo $v$ této práci nazvali Klučky Trojmezí. Dalším bodem na hřebeni je bezejmenná skalnatá vyvýšenina s kótou $633 \mathrm{~m} \mathrm{n}$. m. Poté již svah nabírá přímý směr do údolí řičky Šporky, které tvoří přirozenou, geologickou a zeměpisnou hranici Českého středohoři a Lužických hor (celý hřbet však již náleží CHKO Lužické hory). $V$ tomto strměji probíhajícím svahu pak ještě nalezneme zajímavou kótu 574 m n. m. Wachstein (někdy Stráž, Strážný). Jde o výraznější bazaltový výchoz, př́i kterém jsou dochované kamenné základy a sklep dřevěného hostince z 20. let 20. století. A dále se níže nachází osada Klučky (náleží obci Polevsko) s dalším, poměrně rozsáhlým opuštěným kamenolomem. Po celém hřbetu Klučky můžeme objevit více než 100 přirozených výcho- 
zů i umělých odkryvů. Vzácně zde bylo zjištěno několik výskytů zajímavější zeolitové mineralizace. Čtyřmi z nich se tato práce bude zabývat podrobněji, další budou zmíněny jen okrajově. Celý hřbet rozdělují katastry Kamenického Šenova, Prysku, Okrouhlé, Polevska a Nového Boru.

Vlastní naleziště Klučky tvoří čtyři dílčí lokality objevené a prozkoumané zejména druhým z autorů (LH) v letech 2018 - 2020. Dílčí lokality byly označeny jako Wachstein (1), Klučky - Stráň (2), Klučky - Parkoviště (3) a Trojmezí (4) (obr. 2). Wachstein je na katastru obce Polevsko, Klučky - Stráň a Klučky - Parkoviště jsou na katastru obce Okrouhlá a Trojmezí na styku katastrů Polevsko, Okrouhlá a Prysk. Jedná se ve všech případech o nově objevené lokality zeolitů, které odtud dosud nebyly studované. Nejbližšími lokalitami zeolitů jsou Zaječí vrch a Poustevna, které jsou vzdálené cca 4 - 5 km v., respektive sv. směrem (Pauliš et al. 2019).

\section{Geologie a petrologie hřbetu Klučky}

O některých zdejších terciérních vyvřelinách píší Wurm a Zimmerhackel (1882), Scheumann (1913), Wurm (1916) a Senger (1929). V historické literatuře jsou z lokality Klučky popisovány pouze vyrostlice olivínu, augitu a rhönitu. Zeolity jsou zmiňovány jen jako blíže neurčené bílé a žlutavé výplně drobných dutin ve vulkanitech a v tmelu pyroklastik. Geologií oblasti se nověji zabýval Shrbený (1963). Lokalitu představuje hřbet vulkanogenních hornin posazených na svrchně křídových sedimentech - pískovcích svrchního turonu a coniaku. Hřbet budují príkrovy vulkanických hornin (spolu s žilami a komínovými brekciemi) a jejich podloží tvoří pyroklastika. Vulkanity př́krovů maji v celém hřbetu podobné složení, které Shrbený popisuje jako olivinický čedič. Svrchní partie jsou tvořeny sklovitým čedičem, někdy s obsahem rhönitu. Nově provedeným studiem výbrusů zdejších

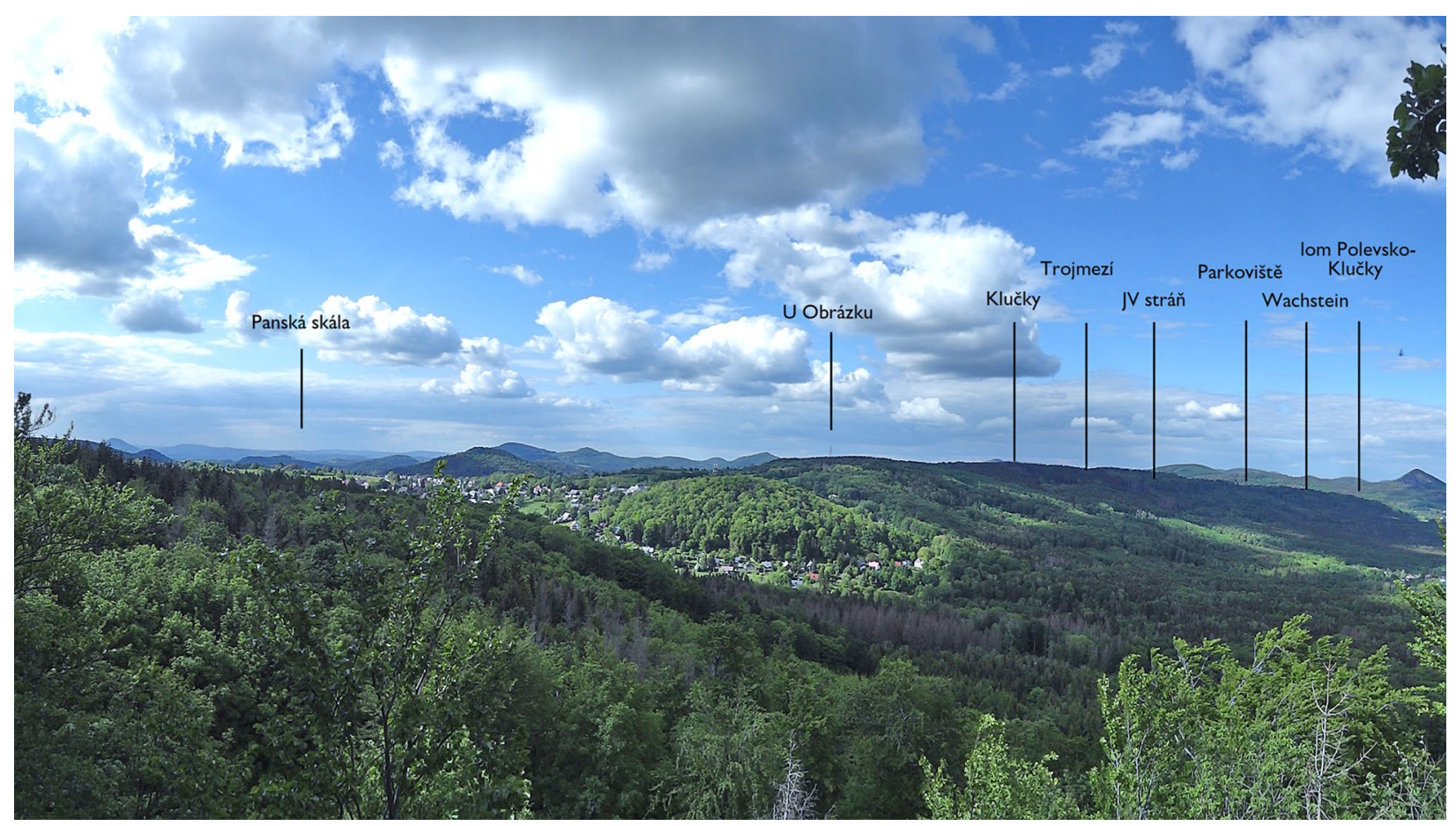

Obr. 1 Celkový pohled na hřeben Klučků, pohled z České skály, foto L. Hrůzek.

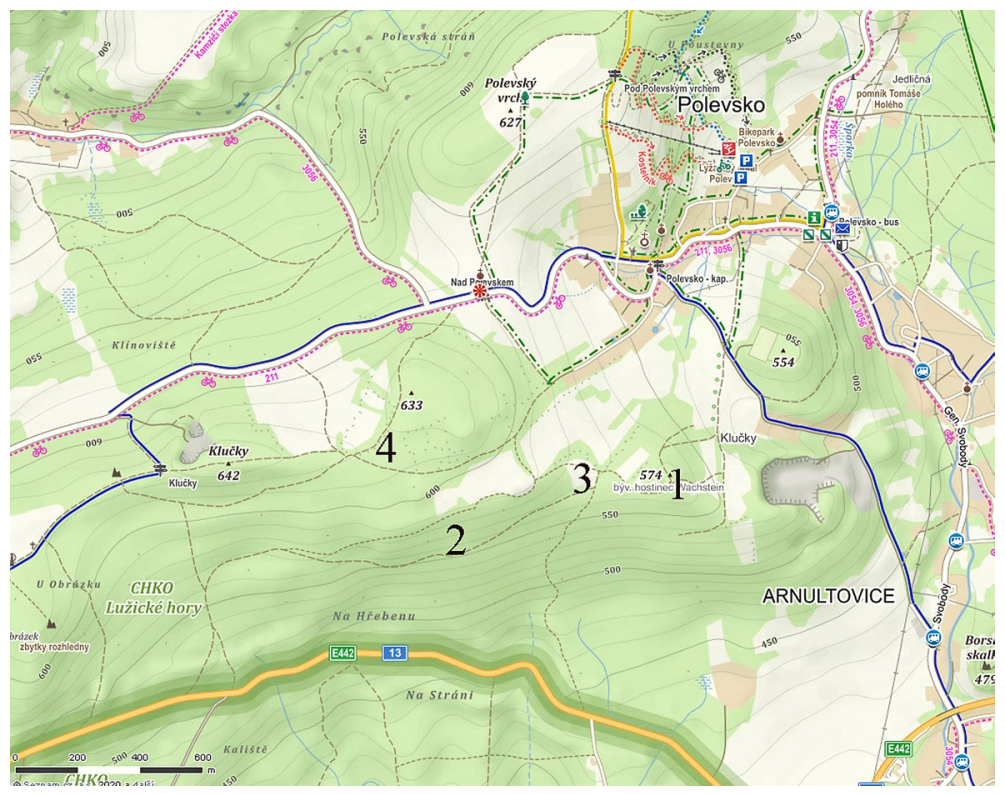

Obr. 2 Plánek dílčích lokalit: 1 - Wachstein, 2 - Klučky - Strán̆, 3 - Klučky - Parkoviště, 4 - Trojmezí; upraveno podle www. mapy.cz. 
čedičových hornin (FF) byly vulkanity klasifikovány jako nefelinicko-analcimický bazanit. Pyroklastika, která jsou tvořena středně zrnitým až hrubozrnným aglomerátem se zcela zjílovělou základní hmotou, dosahují mocnosti kolem $50 \mathrm{~m}$, ojediněle až $80 \mathrm{~m}$. V počátcích vulkanického vývoje území vyplnily širokou mělkou depresi ve svrchně křídové parovině kopírující dnešní údolí řičky Kamenice. Aglomerát je tvořený úlomky pevných tmavošedých vulkanitů, šedých až hnědých jílovitě zcela rozložených vulkanitů, silně porézních jílovitě navětralých vyvřelin, zaoblenými zrny křemene, drobnými krystaly pyroxenů a olivínu. Úlomky a bloky vulkanitů mohou dosahovat velikosti $0.5 \mathrm{~m}$ až několik metrů. Tmel tvoří zeolity a rezavo-červená celistvá hmota, částečně struskovitá hornina (Shrbený 1963).

\section{Metodika výzkumu}

Rentgenová prášková difrakční data byla získána pomocí práškového difraktometru Bruker D8 Advance (Národní muzeum, Praha) s polovodičovým pozičně citlivým detektorem LynxEye za užití CuKa záření (40kV, 40 mA). Práškové preparáty byly naneseny $v$ acetonové suspenzi na nosič zhotovený z monokrystalu křemíku a následně pak byla pořízena difrakční data ve step-scanning režimu (krok $0.01^{\circ}$, načítací čas $8 \mathrm{~s} / \mathrm{krok}$ detektoru, celkový čas experimentu cca 15 hod.). Pozice jednotlivých difrakčních maxim byly popsány profilovou funkcí Pseudo-Voigt a upřesněny profilovým fitováním v programu HighScore Plus. Mřížkové parametry byly zpřesněny metodou nejmenších čtverců pomocí programu Celref (Laugier, Bochu 2011).

Chemické složení zeolitů bylo kvantitativně studováno pomocí elektronového mikroanalyzátoru Cameca SX100 (Národní muzeum, Praha, analytik J. Sejkora a Z. Dolníček) za podmínek: vlnově disperzní analýza, napětí 15 $\mathrm{kV}$, proud $10 \mathrm{nA}$, průměr svazku $2 \mu \mathrm{m}$, standardy: baryt $(\mathrm{BaL} \beta)$, albit (NaKa), sanidin (SiKa, AlKa, KKa), rodonit $(\mathrm{MnK \alpha})$, diopsid $(\mathrm{MgK \alpha})$, apatit $(\mathrm{PK} \alpha)$, hematit $(\mathrm{FeK \alpha})$, $\mathrm{ZnO}(\mathrm{ZnK \alpha})$, celestin (SKa, SrL $\beta)$, Cs sklo (CsKa), wollastonit (CaKa) a topaz (FKa). Obsahy Cs, Fe, Mg, Mn, P, $\mathrm{S}, \mathrm{Zn}$ a $\mathrm{F}$ byly pod mezí detekce prístroje (cca 0.03 - 0.05 hm. \%). Získaná data byla korigována za použití software PAP (Pouchou, Pichoir 1985).

Ramanovo spektrum faujasitu-Na bylo pořizeno za pomoci disperzního spektrometru DXR (Thermo Scientific) spojeného s konfokálním mikroskopem Olympus (Národní muzeum Praha). Podmínky měření: zvětšení objek-

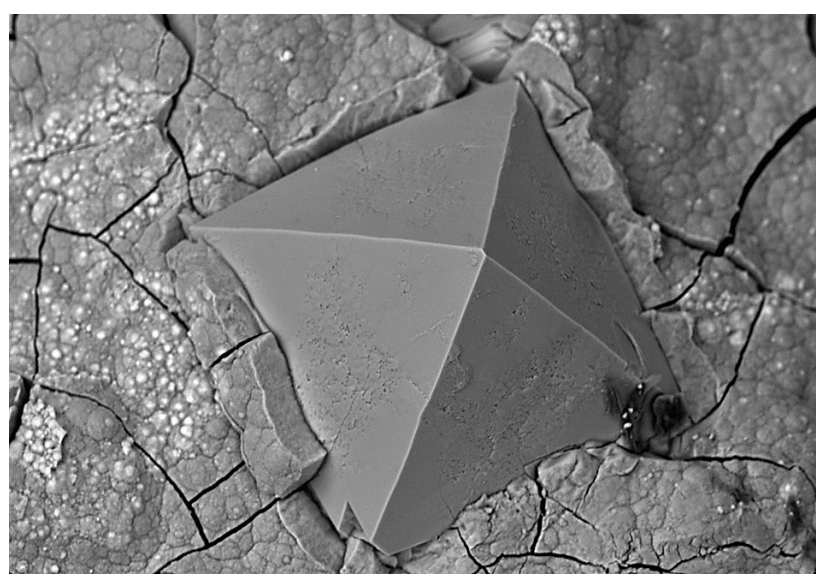

Obr. 4 Oktaedrický krystal faujasitu-Na z Wachsteinu; šiřka záběru $0.4 \mathrm{~mm}$, BSE foto $B$. Ekrt. tivu $20 \times$, použitý laser 633 nm, rozsah měření 45 - 1200 $\mathrm{cm}^{-1}$, doba expozice $1800 \mathrm{~s}$, výkon laseru $4 \mathrm{~mW}$, apertura $50 \mu \mathrm{m}$ pinhole, velikost měřené stopy $1.6 \mu \mathrm{m}$. Možné termické poškození měřených bodů sledované pomocí vizuální kontroly povrchu vzorku po měření a případných změn spektra $v$ průběhu měření, nebylo zjištěno. Spektrometr byl kalibrován pomocí softwarově rízené procedury s využitím emisních linií neonu (kalibrace vinočtu), Ramanových pásů polystyrénu (kalibrace frekvence laseru) a standardizovaného zdroje bílého světla (kalibrace intenzity). Získaná spektra byla zpracována pomocí programu Omnic 9 (Thermo Scientific).

\section{Charakteristika lokalit a jejich mineralizace}

\section{Lokalita Wachstein}

Lokalita se nachází ve východní části vulkanického hřbetu Klučky, východně od kóty 574 m n. m., nedaleko bývalého hostince Wachstein (GPS: $50^{\circ} 46^{4} 45.1^{\prime \prime ~} \mathrm{~N}$; $14^{\circ} 31^{\prime} 50.1^{\prime \prime E}$ ). Vlastní lokalitu tvoří drobný, několik metrů vysoký a asi $50 \mathrm{~m}$ dlouhý hřbet vulkanické horniny (obr. 3). Vulkanit je velmi hrubě sloupcový, rozpadlý do nepravidelných kusů s malým množstvím drobných dutin. Zajímavá zeolitová mineralizace byla zjištěna na dvou místech, z nichž významné je prakticky jen malé sedlo uprostřed hřbetu, kde se na ploše asi $2 \mathrm{~m}^{2}$ nacházeji ve vulkanitu drobné dutiny $s$ faujasitem- $\mathrm{Na}$, offretitem, chabazitem-K a phillipsitem-K. Dutiny mají velmi nepravidelný tvar, jsou členité, ve vulkanitu řídce rozptýlené, jejich velikost obvykle dosahuje jen několika mm, vzácněji

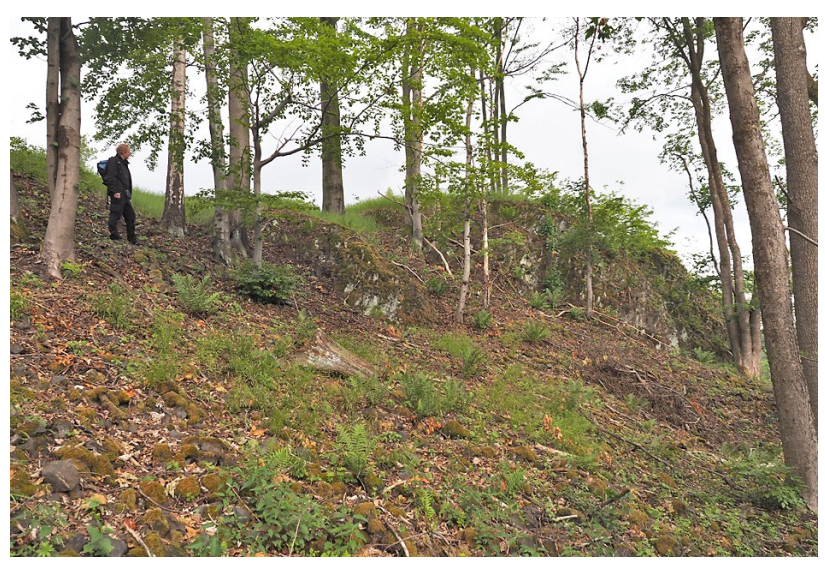

Obr. 3 Celkový pohled skalní výchoz na Wachsteinu, foto P. Pauliš, 2020.

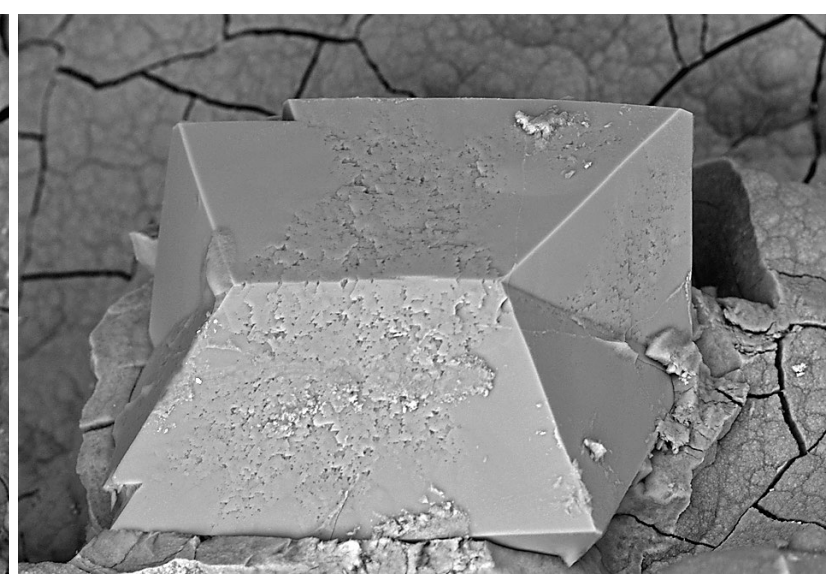

Obr. 5 Krystalové dvojče faujasitu-Na z Wachsteinu; šírka záběru $0.3 \mathrm{~mm}$, BSE foto B. Ekrt. 


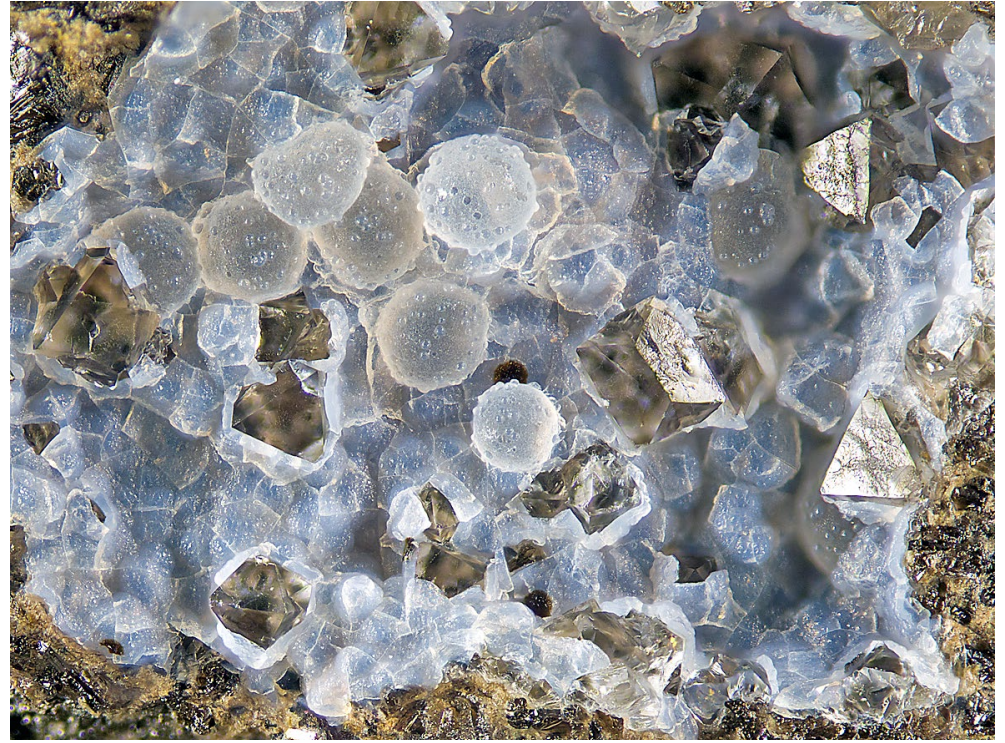

Obr. 6 Charakteristická ukázka dutiny s faujasitem-Na a mladšími offretitem a jílovým minerálem z Wachsteinu; šířka záběru $2 \mathrm{~mm}$, foto P. Fuchs.

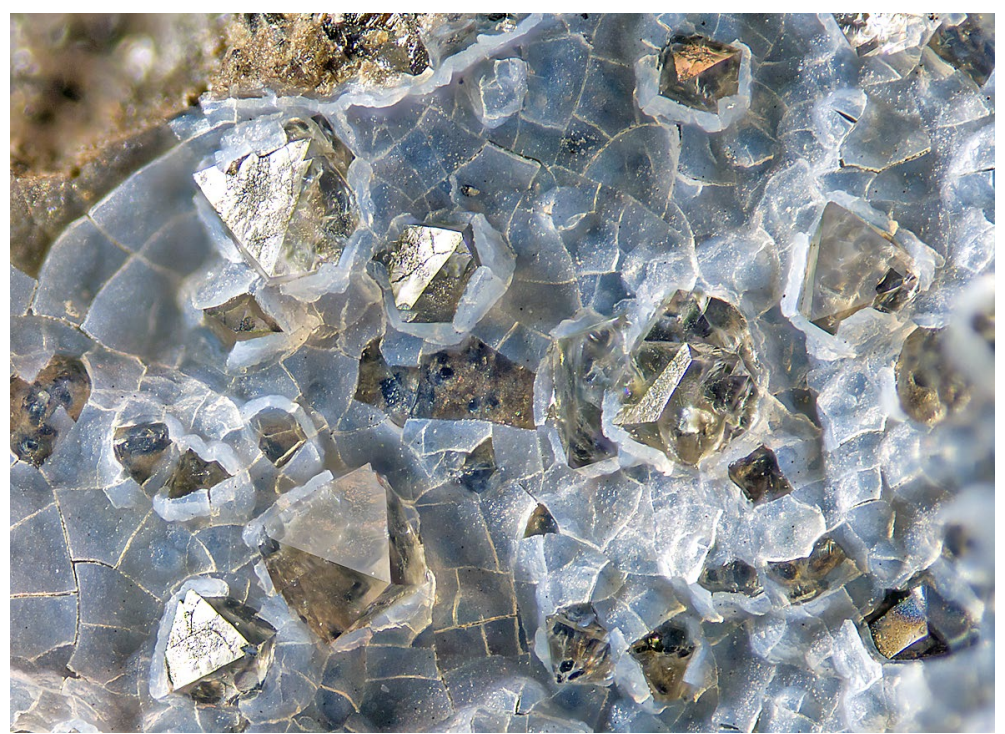

Obr. 7 Faujasit-Na z Wachsteinu; šírka záběru 2 mm, foto P. Fuchs. se objevuji dutiny o velikosti kolem $1 \mathrm{~cm}$ či větší. Vzorky upoutají svojí podobností s lokalitou Sasbach v Kaiserstuhlu (Německo), a to jak minerální asociací, jílovou podložkou, tak celkovým vzhledem dutin. Jen množství phillipsitu je na Wachsteinu menší a velikost dutin i krystalů faujasitu téměř o řád nižší.

Bazaltoidní hornina, ve které jsou drobné dutiny se zeolitovou výplní, je nahnědle tmavošedá až černošedá s nehojnými okrově až rezavě hnědými puklinovými povlaky. $\checkmark$ extrémně jemnozrnné základní hmotě jsou řídce vtroušené a nepřiliš nápadné bělavé fenokrysty o rozměrech kolem $1 \mathrm{~mm}$, ojediněle až $2 \mathrm{~mm}$. Dalším, rovněž nepríliš výrazným makroprvkem, jsou nehojné oválné dutiny o velikosti do dvou mm, jejichž stěny mívají tenkou bílou minerální kưru. Zrnitost základní hmoty je výrazně pod hranicí makroskopické rozlišitelnosti. Horninová hmota se vyznačuje všesměrným uspořádáním postrádajícím jakékoliv projevy paralelní fluidálnosti. Ve výbruse pod mikroskopem výrazně vynikne porfyrická struktura horniny, která v makropohledu nápadná není. Porfyrické vyrostlice o úhrnném podílu přibližně $20 \%$ celkového horninového objemu tvoří zhruba stejným podílem klinopyroxen a olivín, obojí v automorfním omezení. Pyroxen má zonální stavbu s úzkými nafialovělými okraji a slabě nahnědlým vnitřkem. Není postižen ani magmatickou resorbcí, ani druhotnými alteracemi. Naproti tomu vyrostlice olivínu jsou totálně iddingsitizovány. Dominantním minerálem základní hmoty je drobně sloupcovitý až izometricky zrnitý klinopyroxen. Se značným kvantitativním odstupem ho doplňuji zrna magnetitu a lišty plagioklasu labradoritového složení. V základní hmotě se neobjevuje olivín, nebyl v ní zjištěn žádný foid a nevyskytuje se ani sopečné sklo. Struktura horniny je výrazně porfyrická s mikrokrystalickou strukturou základní hmoty, textura je všesměrná. Na základě mikroskopické-

Tabulka 1 Rentgenová prášková data faujasitu-Na z Wachsteinu

\begin{tabular}{|c|c|c|c|c|c|c|c|c|c|c|c|c|c|c|c|c|c|}
\hline$h$ & $k$ & I & $d_{o b s}$ & $I_{o b s}$ & $d_{\text {calc }}$ & $h$ & $k$ & I & $d_{o b s}$ & $I_{o b s}$ & $d_{\text {calc }}$ & $h$ & $k$ & I & $d_{o b s}$ & $I_{o b s}$ & $d_{\text {calc }}$ \\
\hline 1 & 1 & 1 & 14.271 & 100 & 14.248 & 5 & 5 & 5 & 2.852 & 13 & 2.850 & 9 & 5 & 9 & 1.8052 & 1 & 1.8046 \\
\hline 0 & 2 & 2 & 8.734 & 7 & 8.725 & 0 & 4 & 8 & 2.761 & 7 & 2.759 & 7 & 5 & 11 & 1.7680 & 1 & 1.7672 \\
\hline 1 & 1 & 3 & 7.452 & 4 & 7.441 & 3 & 5 & 7 & 2.711 & 2 & 2.709 & 10 & 6 & 8 & 1.7463 & 4 & 1.7450 \\
\hline 2 & 2 & 2 & 7.130 & 2 & 7.124 & 4 & 6 & 6 & 2.632 & 8 & 2.631 & 7 & 9 & 9 & 1.7000 & 2 & 1.6989 \\
\hline 3 & 1 & 3 & 5.668 & 24 & 5.661 & 1 & 3 & 9 & 2.5891 & 2 & 2.5869 & 7 & 7 & 11 & 1.6676 & $<1$ & 1.6676 \\
\hline 2 & 2 & 4 & 4.999 & 5 & 5.037 & 4 & 4 & 8 & 2.5190 & 3 & 2.5186 & 12 & 4 & 8 & 1.6504 & $<1$ & 1.6488 \\
\hline 3 & 3 & 3 & 4.754 & 13 & 4.749 & 2 & 6 & 8 & 2.4217 & 1 & 2.4198 & 15 & 1 & 3 & 1.6069 & $<1$ & 1.6098 \\
\hline 0 & 4 & 4 & 4.367 & 17 & 4.362 & 6 & 6 & 6 & 2.3757 & 3 & 2.3746 & 9 & 9 & 9 & 1.5841 & 2 & 1.5831 \\
\hline 3 & 1 & 5 & 4.168 & 1 & 4.171 & 7 & 5 & 7 & 2.2256 & 1 & 2.2251 & 0 & 0 & 16 & 1.5419 & $<1$ & 1.5423 \\
\hline 2 & 0 & 6 & 3.905 & 4 & 3.902 & 0 & 8 & 8 & 2.1829 & 5 & 2.1812 & 13 & 3 & 9 & 1.5347 & 1 & 1.5343 \\
\hline 5 & 3 & 3 & 3.766 & 29 & 3.763 & 5 & 5 & 9 & 2.1510 & 1 & 2.1561 & 13 & 7 & 7 & 1.5109 & $<1$ & 1.5102 \\
\hline 4 & 4 & 4 & 3.566 & 1 & 3.562 & 9 & 3 & 7 & 2.0937 & 2 & 2.0931 & 12 & 8 & 8 & 1.4971 & 1 & 1.4963 \\
\hline 5 & 1 & 5 & 3.459 & 3 & 3.456 & 4 & 8 & 8 & 2.0577 & 2 & 2.0565 & 0 & 12 & 12 & 1.4550 & $<1$ & 1.4541 \\
\hline 2 & 4 & 6 & 3.301 & 13 & 3.298 & 7 & 7 & 7 & 2.0354 & $<1$ & 2.0354 & 7 & 11 & 11 & 1.4482 & $<1$ & 1.4466 \\
\hline 3 & 5 & 5 & 3.215 & 3 & 3.213 & 10 & 4 & 6 & 1.9964 & $<1$ & 2.0016 & 10 & 10 & 10 & 1.4219 & $<1$ & 1.4248 \\
\hline 0 & 0 & 8 & 3.084 & 1 & 3.085 & 1 & 9 & 9 & 1.9291 & $<1$ & 1.9329 & 1 & 9 & 15 & 1.4085 & $<1$ & 1.4084 \\
\hline 6 & 4 & 4 & 2.996 & 5 & 2.993 & 7 & 7 & 9 & 1.8456 & 1 & 1.8445 & 9 & 11 & 11 & 1.3727 & $<1$ & 1.3731 \\
\hline 0 & 6 & 6 & 2.911 & 9 & 2.908 & 2 & 6 & 12 & 1.8188 & 1 & 1.8193 & & & & & & \\
\hline
\end{tabular}


ho studia Ize tuto horninu klasifikovat jako melanokratní iddingsitizovaný olivinický bazalt.

Nejzajímavějším minerálem zjištěným na lokalitě je jednoznačně faujasit-Na, pro který je tato lokalita jeho prvním ověřeným výskytem v České republice. Faujasit uvedl do mineralogického systému Damour v roce 1842 , který ho pojmenoval na počest francouzského mineraloga Barthelemy Faujase de Saint-Fonda (1741-1819). Krystaluje v kubické soustavě a oktaedr je jeho typickým a prakticky jediným krystalovým tvarem. Na všech známých lokalitách vytváří běžně dvojčata srůstající podle tzv. spinelového zákona. Vyskytuje se $v$ podobě jen velice drobných, bezbarvých až bělavých, ale i nahnědlých, skelně lesklých krystalů dobře štěpných podle $\{111\}$. Krystaly dosahují velikosti do $1 \mathrm{~mm}$, obvykle jsou ale menší (0.1 až $0.3 \mathrm{~mm}$ ). Větší, dosahující 2 až $3 \mathrm{~mm}$, se nacházejí pouze na jeho nejbohatší lokalitě v pohoří Kaiserstuhl v německém Bádensku - na vrchu Limberg u Sasbachu.

V kationtu faujasitů se běžně objevuje sodík, vápník a hořčík, vzácnější je draslík, ve velmi malém množství i stroncium. Podle klasifikace zeolitů (Coombs et al. 1997)

Tabulka 2 Parametry základní cely faujasitu (pro kubickou prostorovou grupu Fd-3m)

\begin{tabular}{rcc}
\hline & Wachstein & Halloran Spring Quadrangle \\
\hline$a[\AA]$ & tato práce & Wise (1982) \\
$V\left[\AA^{3}\right]$ & $24.6775(9)$ & $24.638(3)$ \\
\hline
\end{tabular}

Tabulka 3 Chemické složení faujasitu-Na z Wachsteinu (hm. \%)

\begin{tabular}{lrrrrrrrr}
\hline & mean & 1 & 2 & 3 & 4 & 5 & 6 & 7 \\
\hline $\mathrm{SiO}_{2}$ & 53.78 & 55.61 & 56.10 & 55.08 & 48.82 & 52.47 & 53.09 & 55.32 \\
$\mathrm{Al}_{2} \mathrm{O}_{3}$ & 18.31 & 18.93 & 18.81 & 19.37 & 16.51 & 17.40 & 18.60 & 18.53 \\
$\mathrm{MgO}$ & 0.57 & 0.58 & 0.59 & 0.49 & 0.62 & 0.60 & 0.50 & 0.62 \\
$\mathrm{CaO}$ & 6.69 & 7.13 & 7.04 & 7.04 & 6.52 & 6.37 & 6.45 & 6.28 \\
$\mathrm{~K}_{2} \mathrm{O}$ & 1.62 & 1.77 & 1.23 & 1.62 & 2.01 & 1.06 & 1.94 & 1.73 \\
$\mathrm{Na}_{2} \mathrm{O}$ & 4.68 & 4.53 & 4.14 & 5.18 & 4.32 & 3.82 & 5.76 & 5.00 \\
$\mathrm{H}_{2} \mathrm{O}$ & 28.77 & 29.74 & 29.73 & 29.75 & 26.27 & 27.70 & 28.77 & 29.42 \\
\hline total & 114.42 & 118.29 & 117.64 & 118.53 & 105.07 & 109.42 & 115.11 & 116.90 \\
\hline $\mathrm{Si}^{4+}$ & 8.408 & 8.409 & 8.485 & 8.327 & 8.357 & 8.520 & 8.298 & 8.456 \\
$\mathrm{Al}^{3+}$ & 3.374 & 3.375 & 3.353 & 3.452 & 3.330 & 3.331 & 3.426 & 3.337 \\
$\mathrm{Mg}^{2+}$ & 0.132 & 0.131 & 0.133 & 0.111 & 0.158 & 0.145 & 0.116 & 0.141 \\
$\mathrm{Ca}^{2+}$ & 1.121 & 1.155 & 1.141 & 1.140 & 1.195 & 1.108 & 1.080 & 1.029 \\
$\mathrm{~K}^{+}$ & 0.323 & 0.342 & 0.238 & 0.312 & 0.438 & 0.220 & 0.387 & 0.338 \\
$\mathrm{Na}^{+}$ & 1.418 & 1.328 & 1.214 & 1.519 & 1.434 & 1.202 & 1.745 & 1.452 \\
\hline$\Sigma \mathrm{Mg}^{+\mathrm{Ca}+\mathrm{K}+\mathrm{Na}}$ & 2.994 & 2.956 & 2.726 & 3.082 & 3.225 & 2.675 & 3.328 & 2.990 \\
\hline $\mathrm{H}_{2} \mathrm{O}$ & 15 & 15 & 15 & 15 & 15 & 15 & 15 & 15 \\
$\mathrm{~T}_{\mathrm{Si}}$ & 0.71 & 0.71 & 0.72 & 0.71 & 0.72 & 0.72 & 0.71 & 0.72 \\
\hline $\mathrm{Empin}$
\end{tabular}

Empirický vzorec byl přepočten na bázi 24 kyslíků. $\mathrm{H}_{2} \mathrm{O}$ bylo dopočítáno na základě teoretického obsahu $15 \mathrm{H}_{2} \mathrm{O}$.

Obr. 8 Ramanovo spektrum faujasituNa z Wachsteinu.

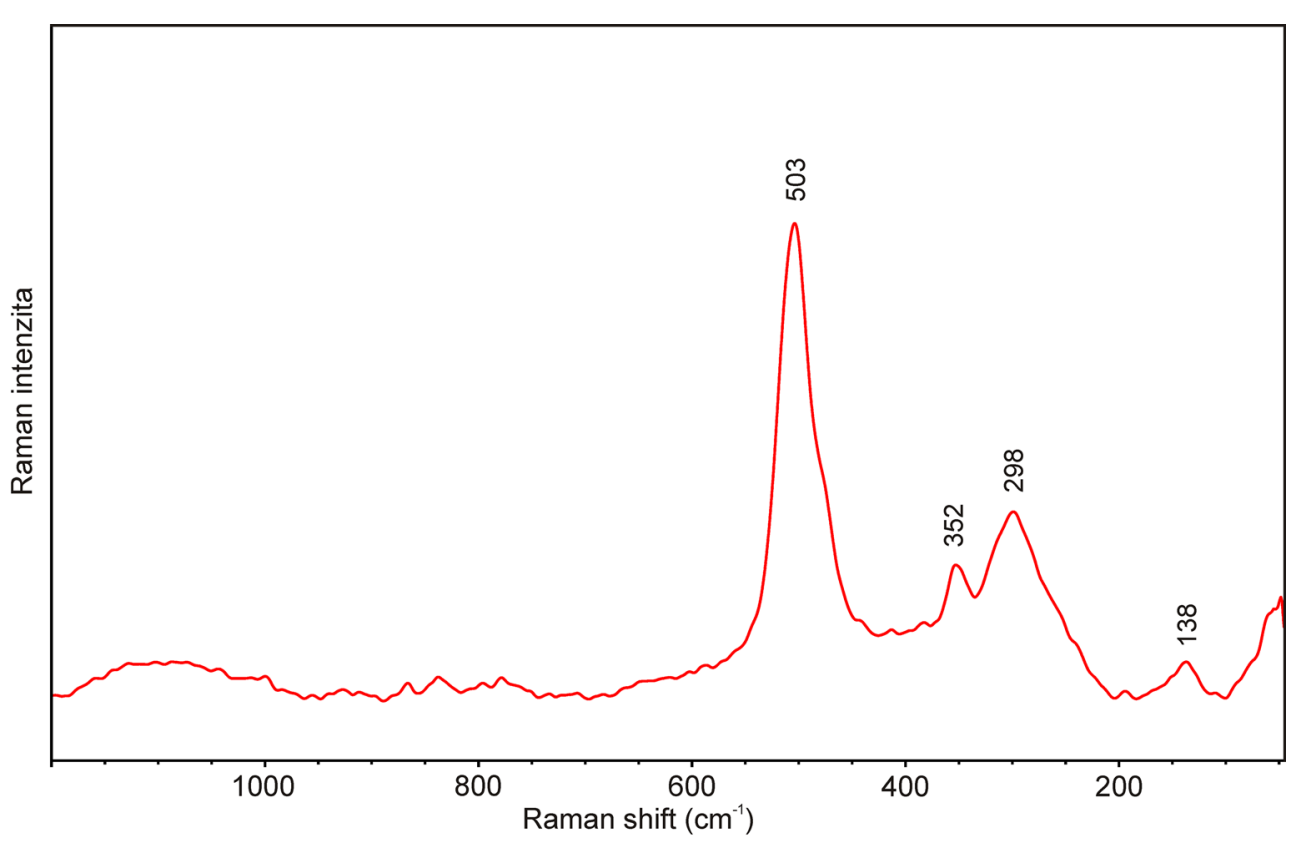


se na základě převažujícího kationtu jako samostatné minerály uznávají faujasit-Na, faujasit-Ca a faujasit-Mg. První dva se vyskytují běžně, faujasit-Mg je vzácný. Typovou lokalitou faujasitu-Na a faujasitu-Mg je výše uvedený Sasbach v pohoří Kaiserstuhl, přičemž faujasit-Mg byl stanoven na základě mikroanalýzy „starého vzorku“ ze Sasbachu uloženého ve sbírce Pennsylvania State University (Genth Collection). Typovou lokalitou faujasitu-Ca je Haselborn $v$ pohoří Vogelsberg $v$ německém Hessensku, vzorky pocházejí z vrtného jádra.

Problémem faujasitu je značně proměnlivé chemické složení jeho krystalů nejen v rámci jedné lokality, ale i jediné dutiny, což dokládá Rinaldi et al. (1975) právě na příkladu lokality Sasbach. Zde se zřejmě vyskytují všechny tři druhy faujasitu, včetně faujasitu bohatého draslíkem, přičemž makroskopicky i mikroskopicky je nelze nijak odli-

Tabulka 4 Rentgenová prášková data offretitu z Wachsteinu

\begin{tabular}{cccccccccccccccccc}
\hline$h$ & $k$ & $l$ & $d_{o b s}$ & $l_{\text {obs }}$ & $d_{\text {calc }}$ & $h$ & $k$ & $l$ & $d_{\text {obs }}$ & $l_{\text {obs }}$ & $d_{\text {calc }}$ & $h$ & $k$ & $l$ & $d_{o b s}$ & $l_{\text {obs }}$ & $d_{\text {calc }}$ \\
\hline 0 & 1 & 0 & 11.577 & 83 & 11.528 & 0 & 2 & 2 & 3.179 & 6 & 3.171 & 3 & 4 & 0 & 1.8955 & 2 & 1.8952 \\
0 & 0 & 1 & 7.580 & 6 & 7.593 & 1 & 3 & 1 & 2.950 & 3 & 2.947 & 2 & 5 & 0 & 1.8459 & 5 & 1.8460 \\
1 & 1 & 0 & 6.660 & 74 & 6.656 & 1 & 2 & 2 & 2.861 & 43 & 2.862 & 1 & 4 & 3 & 1.7825 & 4 & 1.7843 \\
0 & 1 & 1 & 6.345 & 7 & 6.341 & 0 & 4 & 1 & 2.686 & 12 & 2.694 & 1 & 6 & 0 & 1.7593 & 1 & 1.7580 \\
0 & 2 & 0 & 5.765 & 39 & 5.764 & 0 & 0 & 3 & 2.5367 & 2 & 2.5311 & 0 & 6 & 2 & 1.7125 & 4 & 1.7143 \\
0 & 2 & 1 & 4.583 & 14 & 4.591 & 1 & 4 & 0 & 2.5162 & 32 & 2.5156 & 4 & 4 & 0 & 1.6649 & 20 & 1.6639 \\
1 & 2 & 0 & 4.359 & 100 & 4.357 & 2 & 3 & 1 & 2.4966 & 13 & 2.4976 & 2 & 6 & 0 & 1.5958 & 7 & 1.5986 \\
0 & 3 & 0 & 3.843 & 60 & 3.843 & 0 & 5 & 0 & 2.3049 & 1 & 2.3056 & 2 & 6 & 1 & 1.5649 & 2 & 1.5644 \\
1 & 2 & 1 & 3.779 & 65 & 3.779 & 3 & 3 & 0 & 2.2186 & 22 & 2.2186 & 1 & 4 & 4 & 1.5159 & $<1$ & 1.5153 \\
0 & 1 & 2 & 3.600 & 15 & 3.606 & 3 & 3 & 1 & 2.1304 & 5 & 2.1295 & 4 & 5 & 0 & 1.4761 & 1 & 1.4760 \\
0 & 3 & 1 & 3.430 & 5 & 3.429 & 2 & 4 & 1 & 2.0936 & 4 & 2.0941 & 3 & 3 & 4 & 1.4419 & 1 & 1.4424 \\
2 & 2 & 0 & 3.329 & 31 & 3.328 & 1 & 5 & 1 & 1.9980 & 4 & 1.9976 & 4 & 4 & 3 & 1.3902 & 1 & 1.3904 \\
1 & 3 & 0 & 3.200 & 7 & 3.197 & 0 & 5 & 2 & 1.9707 & 1 & 1.9707 & 4 & 5 & 2 & 1.3758 & 2 & 1.3757 \\
\hline
\end{tabular}

Tabulka 5 Parametry základní cely offretitu (pro hexagonální prostorovou grupu P-6m2)

\begin{tabular}{llccc}
\hline & & $a[\AA]$ & $c[\AA]$ & $V\left[\AA^{3}\right]$ \\
\hline Wachstein & tato práce & $13.311(6)$ & $7.5934(6)$ & $1165.2(5)$ \\
Stráň & tato práce & $13.310(5)$ & $7.5886(5)$ & $1164.3(4)$ \\
Poustevna & Pauliš et al. (2019) & $13.312(5)$ & $7.5907(5)$ & $1164.9(6)$ \\
Zaječí vrch & Pauliš et al. (2019) & $13.304(5)$ & $7.5998(4)$ & $1164.9(7)$ \\
Mt. Semiol & Gualtieri et al. (1998) & $13.293(2)$ & $7.608(1)$ & 1164.25 \\
Kluček & Pauliš et al. (2018a) & $13.302(5)$ & $7.5904(12)$ & $1163.1(6)$ \\
Okřešice & Pauliš et al. (2017a) & $13.297(8)$ & $7.6008(4)$ & $1163.9(8)$ \\
Nový Oldřichov & Pauliš et al. (2016a) & $13.295(6)$ & $7.6133(4)$ & $1165.4(6)$ \\
Vrbička & Pauliš et al. (2013) & $13.261(7)$ & $7.559(1)$ & $1151.5(1)$ \\
\hline
\end{tabular}

Tabulka 6 Chemické složení offretitu z Wachsteinu (hm. \%)

\begin{tabular}{lrrrrrrr}
\hline & mean & 1 & 2 & 3 & 4 & 5 & 6 \\
\hline $\mathrm{SiO}_{2}$ & 53.10 & 52.12 & 52.75 & 53.44 & 51.87 & 53.98 & 54.40 \\
$\mathrm{Al}_{2} \mathrm{O}_{3}$ & 19.44 & 19.46 & 19.80 & 19.10 & 19.73 & 19.50 & 19.04 \\
$\mathrm{MgO}$ & 0.93 & 1.16 & 1.00 & 0.88 & 0.97 & 0.69 & 0.86 \\
$\mathrm{CaO}$ & 5.16 & 4.78 & 5.12 & 5.14 & 5.18 & 5.48 & 5.28 \\
$\mathrm{SrO}$ & 0.65 & 0.58 & 0.56 & 0.54 & 0.43 & 0.92 & 0.85 \\
$\mathrm{~K} \mathrm{O}$ & 6.70 & 8.02 & 7.31 & 5.77 & 7.85 & 6.08 & 5.18 \\
$\mathrm{H}_{2} \mathrm{O}$ & 20.27 & 20.11 & 20.32 & 20.18 & 20.11 & 20.49 & 20.42 \\
\hline total & 106.25 & 106.23 & 106.86 & 105.05 & 106.14 & 107.14 & 106.03 \\
\hline $\mathrm{Si}^{4+}$ & 12.564 & 12.430 & 12.455 & 12.702 & 12.376 & 12.640 & 12.783 \\
$\mathrm{Al}^{3+}$ & 5.423 & 5.471 & 5.510 & 5.350 & 5.548 & 5.383 & 5.272 \\
$\mathrm{Mg}^{2+}$ & 0.328 & 0.413 & 0.352 & 0.311 & 0.345 & 0.241 & 0.301 \\
$\mathrm{Ca}^{2+}$ & 1.308 & 1.221 & 1.295 & 1.310 & 1.325 & 1.375 & 1.329 \\
$\mathrm{Sr}^{2+}$ & 0.089 & 0.080 & 0.077 & 0.074 & 0.059 & 0.125 & 0.116 \\
$\mathrm{~K}^{+}$ & 2.022 & 2.490 & 2.202 & 1.748 & 2.388 & 1.815 & 1.553 \\
\hline$\Sigma \mathrm{Mg}+\mathrm{Ca}+\mathrm{Sr}+\mathrm{K}$ & 3.747 & 4.204 & 3.926 & 3.443 & 4.117 & 3.556 & 3.299 \\
\hline $\mathrm{H}_{2} \mathrm{O}$ & 16 & 16 & 16 & 16 & 16 & 16 & 16 \\
$\mathrm{~T}_{\mathrm{Si}}$ & 0.70 & 0.69 & 0.69 & 0.70 & 0.69 & 0.70 & 0.71 \\
\hline
\end{tabular}

Empirický vzorec byl přepočten na bázi 36 kyslíků. $\mathrm{H}_{2} \mathrm{O}$ bylo dopočítáno na základě teoretického obsahu $16 \mathrm{H}_{2} \mathrm{O}$. 
šit. Obsahy $\mathrm{Na}, \mathrm{Ca}, \mathrm{Mg}$ i K vzájemně značně kolísají. Obecně Ize faujasity ze Sasbachu označovat za faujasity-Na (Weisenberger, Spürgin 2009). Gottardi, Galli (1985) uvádějí, že chemismus faujasitů je tak variabilní, že může být někdy dost daleko („sometimes quite far") od svého teoretického vzorce.

Faujasit patří mezi vzácnější zeolity, $v$ literatuře a na internetu je možno dohledat kolem 40 lokalit $v 15$ státech a jejich zámořských územích. Nejrozsáhlejší, ale zdaleka ne úplný výčet lokalit Ize nalézt na stránkách www.mindat.org. Starší sběry shrnuje Tschernich (1992). Z rady lokalit není známé jeho chemické složení, na některých byl určen pouze makroskopicky. Faujasit je jistě rozšířen $v$ daleko větším množství, díky svým malým rozměrům ovšem často uniká pozornosti. Geneticky se faujasit na naprosté většině lokalit objevuje spolu s dalšími zeolity (hlavně chabazitem, phillipsitem a offretitem) $v$ dutinkách mladých (terciér, kvartér) bazaltoidních hornin. $V$ Kanadě byl ale zjištěn i v masívu alkalických vyvřelých hornin v Mont Saint Hillaire, na žilách v prekambrických metapyroxenitech v Ontariu a spolu s fluoritem je uváděn $z$ pyroxenitu $v$ dole na slídu Daisy Mica Mine v Quebecu. Ve starší literatuře je uváděn i z masívu St. Gotthard ve Švýcarsku. Diagenetický faujasit v mikrokrystalické formě se vyskytuje $v$ hydrotermálně alterovaných tufech na Blízkém východu, Arabském poloostrově a Havajských ostrovech.

V České republice byl výskyt faujasitu uváděn ze známé zeolitové lokality Dobrná u Děčína. Na přednášce, $v$ rámci 2. semináře České zeolitové skupiny 31. 5. 1997 v Turnově, R. Rychlý uvedl, že „Při revizi asi $2 \mathrm{~mm}$ čirých skelných krystalů $z$ dutin bazaltické horniny z lokality Dobrná u Děčína byl pomocí rtg. difrakční analýzy identifikován faujasit“ (Rychlý, Tschernich 1997, 1998). Bohužel, jediný vzorek již nežijícího sběratele J. Bárty z Děčína, ani rentgenový záznam se autorům nepodařilo dohledat. Výskyt faujasitu tak považujeme za sporný a neprokázaný, zvláště když se v Dobrné běžně vyskytuje tvarově podobný gismondin. Faujasit je též uveden bez bližších charakteristik z Podhorního vrchu u Mariánských Lázní s odkazem na muzejní sbírky (Kratochvíl 1962). Jde o čtyři vzorky z této lokality, které jsou uloženy ve sbírkách Národního muzea $\vee$ Praze pod označením faujasit. Prohlídkou vzorků bylo zjištěno, že jde o záměnu za vcelku běžné izometrické krystaly phillipsitu. Obě údajné české lokality faujasitu Ize tedy považovat za problematické.

Faujasit-Na tvoří na Wachsteinu charakteristické oktaedrické krystaly (obr. 4) velikosti jen do $0.2 \mathrm{~mm}$, vzácněji $0.3 \mathrm{~mm}$, ne větší. Běžně tvoři i dvojčata podle spinelového zákona (obr. 5), a to i vícečetná. Krystaly jsou bezbarvé, průhledné, skelně lesklé, někdy matné. $\vee$ drobných dutinách mají tmavý

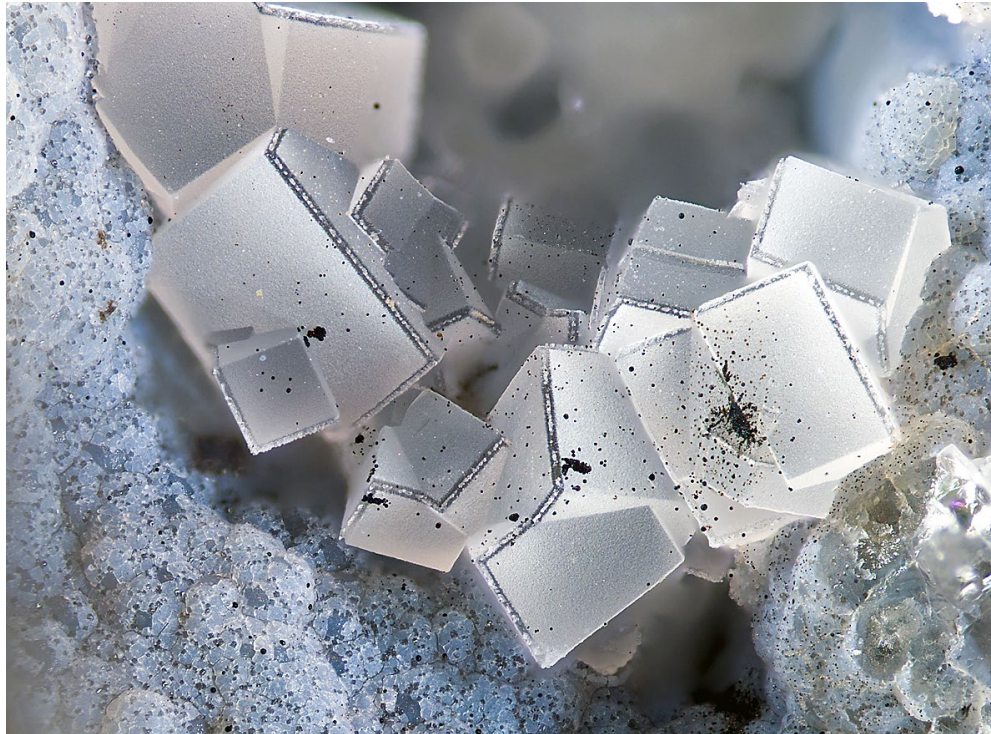

Obr. 9 Nárůsty offretitu na chabazitu z Wachsteinu; šírka záběru 2 mm, foto P. Fuchs.

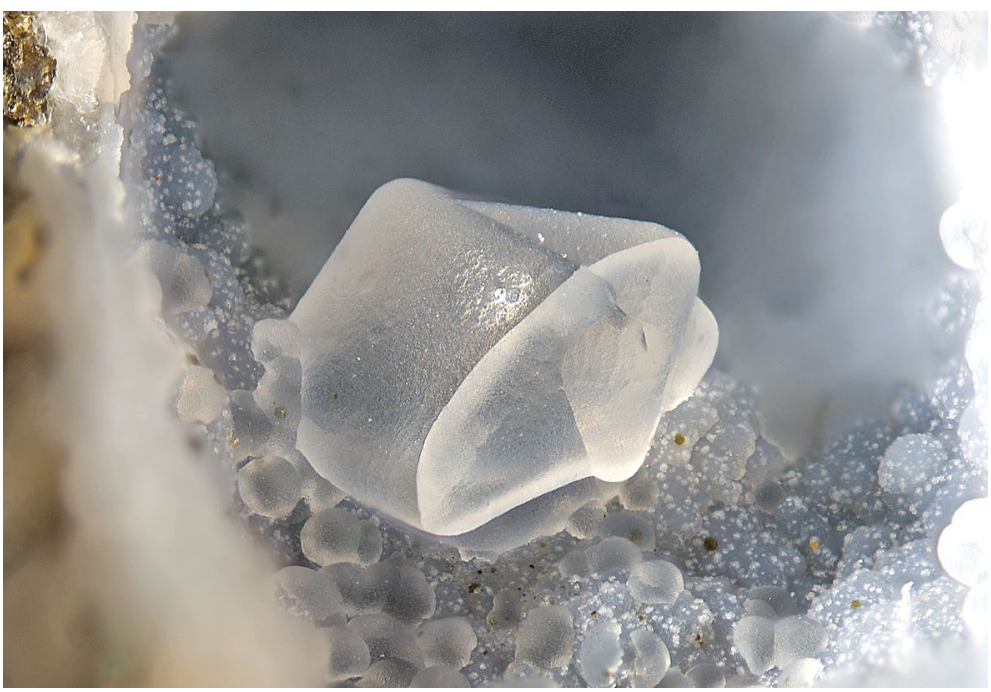

Obr. 10 Offretit narůstající na chabazit z Wachsteinu; šiřka záběru $1.8 \mathrm{~mm}$, foto P. Fuchs.

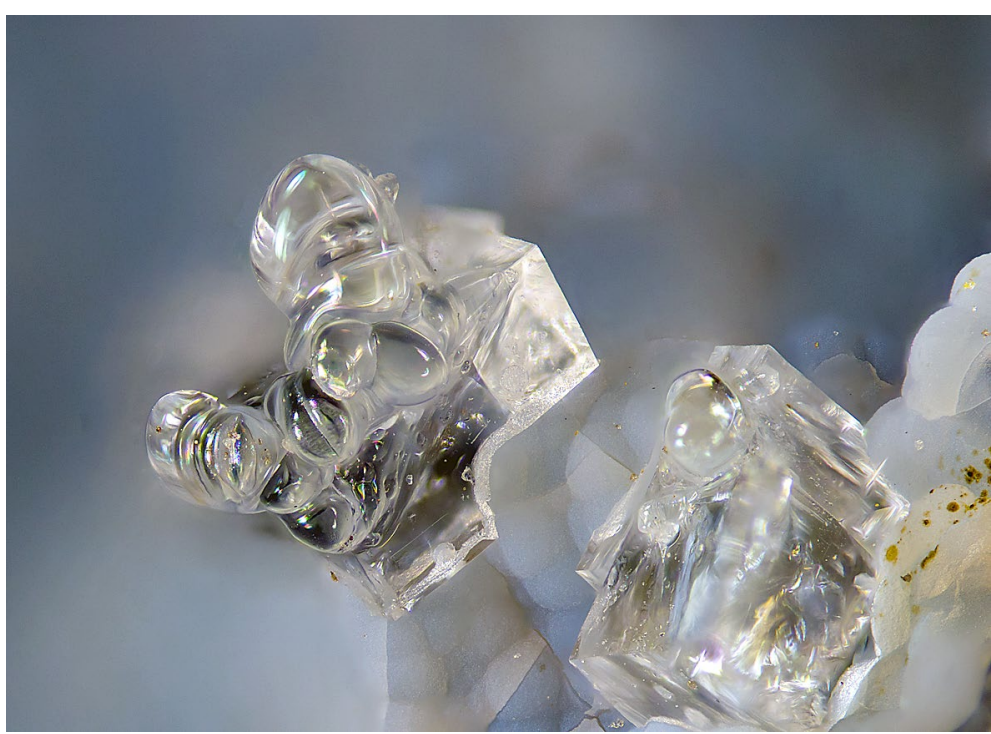

Obr. 11 Hyalit pokrývající krystal chabazitu z Wachsteinu; šírka záběru $2 \mathrm{~mm}$, foto P. Fuchs. 
Tabulka 7 Rentgenová prášková data chabazitu-K z Wachsteinu

\begin{tabular}{cccccccccccccccccc}
\hline$h$ & $k$ & $l$ & $d_{\text {obs }}$ & $l_{\text {obs }}$ & $d_{\text {calc }}$ & $h$ & $k$ & $l$ & $d_{\text {obs }}$ & $l_{\text {obs }}$ & $d_{\text {calc }}$ & $h$ & $k$ & $l$ & $d_{\text {obs }}$ & $l_{\text {obs }}$ & $d_{\text {calc }}$ \\
\hline 1 & 0 & 1 & 9.336 & 89 & 9.363 & 2 & 3 & 2 & 2.5731 & 7 & 2.5793 & 3 & 2 & 7 & 1.6902 & 2 & 1.6913 \\
1 & 1 & 0 & 6.918 & 8 & 6.911 & 1 & 3 & 4 & 2.4916 & 22 & 2.4877 & 3 & 4 & 5 & 1.6481 & 2 & 1.6463 \\
0 & 1 & 2 & 6.333 & 2 & 6.364 & 1 & 1 & 6 & 2.3558 & 1 & 2.3546 & 1 & 6 & 4 & 1.6458 & 4 & 1.6419 \\
0 & 2 & 1 & 5.546 & 12 & 5.560 & 4 & 0 & 4 & 2.3433 & 5 & 2.3407 & 7 & 1 & 0 & 1.5811 & 2 & 1.5855 \\
0 & 0 & 3 & 4.974 & 33 & 5.009 & 3 & 3 & 0 & 2.3092 & 2 & 2.3037 & 3 & 5 & 4 & 1.5551 & 6 & 1.5564 \\
2 & 0 & 2 & 4.662 & 7 & 4.681 & 3 & 1 & 5 & 2.2279 & $<1$ & 2.2280 & 5 & 2 & 6 & 1.5229 & 2 & 1.5221 \\
2 & 1 & 1 & 4.325 & 100 & 4.332 & 4 & 2 & 2 & 2.1652 & 1 & 2.1661 & 6 & 2 & 4 & 1.5185 & 1 & 1.5183 \\
1 & 1 & 3 & 4.034 & 4 & 4.056 & 3 & 0 & 6 & 2.1245 & $<1$ & 2.1212 & 7 & 1 & 3 & 1.5139 & 2 & 1.5116 \\
3 & 0 & 0 & 3.982 & 3 & 3.990 & 1 & 0 & 7 & 2.1103 & $<1$ & 2.1130 & 5 & 3 & 5 & 1.4854 & 1 & 1.4863 \\
1 & 2 & 2 & 3.862 & 22 & 3.876 & 3 & 3 & 3 & 2.0877 & 6 & 2.0929 & 5 & 0 & 8 & 1.4799 & 1 & 1.4778 \\
1 & 0 & 4 & 3.562 & 33 & 3.584 & 1 & 5 & 2 & 2.0629 & 1 & 2.0670 & 8 & 0 & 2 & 1.4718 & $<1$ & 1.4675 \\
2 & 2 & 0 & 3.462 & 4 & 3.456 & 6 & 0 & 0 & 1.9910 & $<1$ & 1.9950 & 2 & 6 & 5 & 1.4539 & $<1$ & 1.4531 \\
1 & 3 & 1 & 3.240 & 4 & 3.242 & 5 & 2 & 0 & 1.9141 & 2 & 1.9168 & 4 & 2 & 8 & 1.4472 & 4 & 1.4451 \\
0 & 2 & 4 & 3.187 & 1 & 3.182 & 5 & 1 & 4 & 1.8671 & 6 & 1.8660 & 5 & 4 & 4 & 1.4189 & 2 & 1.4191 \\
3 & 0 & 3 & 3.099 & $<1$ & 3.121 & 4 & 1 & 6 & 1.8083 & 2 & 1.8078 & 1 & 5 & 8 & 1.4145 & 2 & 1.4145 \\
4 & 0 & 1 & 2.930 & 75 & 2.935 & 1 & 3 & 7 & 1.8011 & 10 & 1.8027 & 8 & 1 & 1 & 1.3968 & 1 & 1.3950 \\
2 & 1 & 4 & 2.893 & 34 & 2.890 & 2 & 0 & 8 & 1.7916 & 1 & 1.7922 & 0 & 8 & 4 & 1.3879 & $<1$ & 1.3901 \\
2 & 2 & 3 & 2.835 & 4 & 2.844 & 6 & 1 & 2 & 1.7713 & 2 & 1.7738 & 2 & 7 & 4 & 1.3629 & 1 & 1.3628 \\
3 & 2 & 1 & 2.696 & 1 & 2.701 & 4 & 4 & 0 & 1.7272 & 3 & 1.7278 & 3 & 4 & 8 & 1.3599 & 1 & 1.3587 \\
4 & 1 & 0 & 2.607 & 9 & 2.612 & 3 & 3 & 6 & 1.6962 & 1 & 1.6955 & & & & & \\
\hline
\end{tabular}

Tabulka 8 Parametry základní cely chabazitu (pro trigonální prostorovou grupu $R-3 m$ )

\begin{tabular}{llllll}
\hline & & & $a[\AA]$ & $c[\AA]$ & $V\left[\AA^{3}\right]$ \\
\hline chabazit-K & Wachstein & tato práce & $13.822(5)$ & $15.0268(5)$ & $2486.2(9)$ \\
chabazit-K & Stráň & tato práce & $13.817(6)$ & $15.0389(5)$ & $2483.4(8)$ \\
chabazit-Ca & Poustevna & Pauliš et al. (2019) & $13.8088(4)$ & $15.0395(3)$ & $2482.5(7)$ \\
chabazit & Zaječí vrch & Pauliš et al. (2019) & $13.819(6)$ & $15.0186(3)$ & $2483.7(8)$ \\
chabazit-Ca & Heřmanice & Pauliš et al. (2018b) & $13.814(5)$ & $15.0449(3)$ & $2486.3(9)$ \\
chabazit-Ca & Chibiny & Yakubovich et al. (2005) & $13.831(3)$ & $15.023(5)$ & 2488.83 \\
chabazit-Ca & Kluček & Pauliš et al. (2018a) & $13.825(5)$ & $15.0289(2)$ & $2487.6(8)$ \\
chabazit-Ca & Tachov & Pauliš et al. (2017b) & $13.833(8)$ & $15.0213(3)$ & $2490(1)$ \\
chabazit-Ca & Svor & Pauliš et al. (2016b) & $13.826(6)$ & $15.0196(3)$ & $2486(1)$ \\
chabazit-Ca & Oldřichov & Pauliš et al. (2016a) & $13.820(7)$ & $15.0364(8)$ & $2487.1(9)$ \\
chabazit-K & Oldřichov & Pauliš et al. (2016a) & $13.832(8)$ & $15.0265(6)$ & $2489(1)$ \\
chabazit-Ca & Hackenberg & Pauliš et al. (2014) & $13.837(6)$ & $15.0073(4)$ & $2488(1)$ \\
chabazit-Ca & Jehla & Pauliš et al. (2015) & $13.820(6)$ & $15.0226(4)$ & $2484.9(1)$ \\
\hline
\end{tabular}

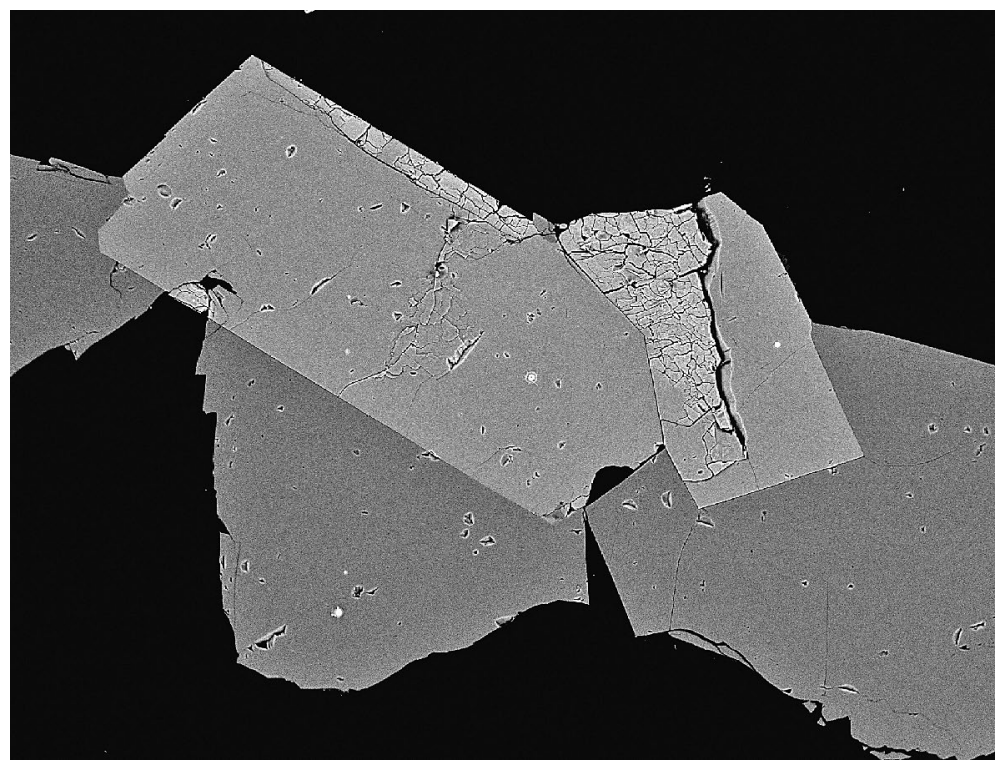

Obr. 12 Srůst krystalů chabazitu-K z Wachsteinu (světlejší $s$ minoritními obsahy Ba); šírka záběru $1 \mathrm{~mm}$, BSE foto J. Sejkora. 
kouřový odstín, který velmi znesnadňuje jejich hledání a který je způsobený prosvítáním černošedě zbarvených stěn dutin, na které krystaly přímo nasedají. Faujasit bývá pokryt drobnými snopkovitými a polokulovitými agregáty mladšího offretitu. Ve většině dutin je pouze jediný krystal faujasitu nebo jich je jen několik. Větší počet (desítky krystalů) je velmi vzácný. Faujasit se $v$ dutinách objevuje pouze $v$ asociaci $s$ offretitem a blíže neurčeným amorfním jílovým minerálem (obr. 6). Ten porůstá stěny dutin $v$ podobě jemného, tmavě modrého filmu (u menších dutin) nebo namodralé, nahnědlé, šedivé polygonálně rozpraskané krusty (obr. 7). Ta je mladší než faujasit, protože jej zcela pokrývá. Stejně jako u vzorků ze Sasbachu ji Ize opatrně z krystalů faujasitu odstranit. Někdy do dutin vystupují z horniny droboučké tabulkové krystaly černého pyroxenu (augitu), obrostlé jílovou krustou, což je též ze Sasbachu známé. Dutiny s faujasitem se objevují v hornině hnízdovitě, je jich často několik pohromadě.

Rentgenová prášková data faujasitu-Na z Wachsteinu (tab. 1) jsou blízká datům pro tento minerální druh, zpřesněné parametry jeho základní cely (tab. 2) dobře odpovídají publikovaným údajům pro tento zeolit. $\mathrm{V}$ BSE obraze je studovaný minerál chemicky homogenní. Při studiu jeho chemického složení (tab. 3) byly zjištěny obsahy $\mathrm{Si}, \mathrm{Al}$, $\mathrm{Ca}, \mathrm{Mg}, \mathrm{Na}$ a K ; ostatní měřené prvky byly pod mezí detekce. Empirický vzorec faujasitu-Na (průměr sedmi bodových analýz) je na bázi 24 kyslíků možno vyjádřit jako $\left(\mathrm{Na}_{1.43} \mathrm{Ca}_{1.20} \mathrm{~K}_{0.44} \mathrm{Mg}_{0.16}\right)_{\Sigma 3.23}\left(\mathrm{Al}_{3.33} \mathrm{Si}_{8.36}\right) \mathrm{O}_{24} \cdot 15$ $\mathrm{H}_{2} \mathrm{O}$. Oproti faujasitu-Na z klasické lokality Sasbach obsahuje zvýšený podíl $\mathrm{CaO}$, $\mathrm{K}_{2} \mathrm{O}$ a podstatně menší podíl MgO. Zvýšené sumy chemických analýz (tab. 3) při započtení teoretického obsahu molekulární vody $\left(15 \mathrm{H}_{2} \mathrm{O}\right)$ jsou patrně způsobeny dehydratací studovaného materiálu ve vakuu elektronového mikroskopu. Hodnota $\mathrm{T}_{\mathrm{Si}}=\mathrm{Si} /(\mathrm{Si}+\mathrm{Al})=$ 0.71 tohoto faujasitu-Na je ve spodní části rozmezí uváděného pro faujasit-Na (Coombs et al. 1997). Ramanovo spektrum faujasituNa z Wachsteinu (obr. 8), dobře odpovídá spektrům pro faujasit-Ca a -Mg obsaženým v databázi RRUFF (www.rruff.info).

Mnohem hojnějším zeolitem než faujasit je na Wachsteinu offretit, který bývá často v dutinách vedle jílového minerálu jediným nerostem. Nejčastěji vytváří bezbarvé či šedivé, snopečkové, polokulovité i hříbečkové agregáty $s$ jemně vláknitou, radiálně paprsčitou stavbou, někdy s hladkým čistým povrchem, častěji s matným, jemně roztřepeným, jakoby „namrzlým“ povrchem. Průměr rozměrů agregátů offretitu se pohybuje mezi $0.2-0.3 \mathrm{~mm}$. Agregáty se v dutinách vyskytují jednotlivě nebo mohou na sebe i narůstat a vytvářet nepatrné krápníky; místy tvoří souvislou ledvinitou kưru. Někdy ze souvislé krusty offretitu, obvykle s hladkým lesklým povrchem, vyčnívají jednotlivé šestiboké jehličky až $1 \mathrm{~mm}$ dlouhé. Jílová krusta nikdy agregáty offretitu neporůstá, ale vzácně může mladší generace jílového minerálu (hm. \%) vytvořit na konci větších sloupečků offretitu drobnou kuličku. Toto bylo pozorováno na řadě lokalit v Českém středohoří i Lužických horách. Offretit obrůstá klence chabazitu, vzácně i fakolitu, a to $v$ podobě jemného matného filmu (pravděpodobně epitaxní nárůst) (obr. 9) nebo i jako souvislé vrstvy z kolmo uspořádaných vláken, která nemá charakter epitaxního nárůstu. Tato vrstva plynule obrůstá a zaobluje i hrany klenců chabazitu (obr. 10).

Rentgenová prášková data offretitu z Wachsteinu (tab. 4) jsou blízká datům pro tento minerální druh, zpřesněné parametry jeho základní cely jsou $v$ tabulce 5 porovnány $s$ publikovaným údaji. $V$ BSE obraze je studovaný

Tabulka 9 Chemické složení Sr-bohatšiho chabazitu-K z Wachsteinu

\begin{tabular}{lrrrrrr}
\hline & mean & 1 & 2 & 3 & 4 & 5 \\
\hline $\mathrm{SiO}_{2}$ & 51.53 & 51.97 & 49.33 & 51.79 & 51.89 & 52.66 \\
$\mathrm{Al}_{2} \mathrm{O}_{3}$ & 16.66 & 16.64 & 16.27 & 16.89 & 17.08 & 16.44 \\
$\mathrm{MgO}$ & 1.62 & 1.52 & 1.13 & 1.89 & 1.76 & 1.78 \\
$\mathrm{CaO}$ & 4.48 & 4.83 & 5.30 & 3.38 & 4.01 & 4.86 \\
$\mathrm{SrO}$ & 0.28 & 0.35 & 0.58 & 0.15 & 0.26 & 0.05 \\
$\mathrm{~K}_{2} \mathrm{O}$ & 9.12 & 8.97 & 6.73 & 10.35 & 9.92 & 6.64 \\
$\mathrm{H}_{2} \mathrm{O}$ & 21.85 & 21.99 & 21.19 & 21.97 & 22.09 & 21.97 \\
\hline total & 105.54 & 106.27 & 103.53 & 106.42 & 107.01 & 104.40 \\
\hline $\mathrm{Si}^{4+}$ & 8.487 & 8.500 & 8.377 & 8.479 & 8.453 & 8.626 \\
$\mathrm{Al}^{3+}$ & 3.234 & 3.208 & 3.257 & 3.258 & 3.278 & 3.173 \\
$\mathrm{Mg}^{2+}$ & 0.398 & 0.371 & 0.286 & 0.461 & 0.428 & 0.435 \\
$\mathrm{Ca}^{2+}$ & 0.791 & 0.846 & 0.964 & 0.593 & 0.699 & 0.853 \\
$\mathrm{Sr}^{2+}$ & 0.027 & 0.033 & 0.057 & 0.015 & 0.024 & 0.005 \\
$\mathrm{~K}^{+}$ & 1.916 & 1.871 & 2.108 & 2.162 & 2.061 & 1.388 \\
\hline$\Sigma \mathrm{Mg}^{+} \mathrm{Ca}+\mathrm{Sr}+\mathrm{K}$ & 3.132 & 3.121 & 3.415 & 3.231 & 3.212 & 2.681 \\
\hline $\mathrm{H}_{2} \mathrm{O}$ & 12 & 12 & 12 & 12 & 12 & 12 \\
$\mathrm{~T}_{\mathrm{Si}}$ & 0.72 & 0.73 & 0.72 & 0.72 & 0.72 & 0.73 \\
\hline
\end{tabular}

Empirický vzorec byl přepočten na bázi 24 kyslíků. $\mathrm{H}_{2} \mathrm{O}$ bylo dopočítáno na základě teoretického obsahu $12 \mathrm{H}_{2} \mathrm{O}$.

Tabulka 10 Chemické složení Ba-bohatšího chabazitu-K z Wachsteinu (hm. \%)

\begin{tabular}{|c|c|c|c|c|c|c|}
\hline & mean & 1 & 2 & 3 & 4 & 5 \\
\hline $\mathrm{SiO}_{2}$ & 49.45 & 48.67 & 49.19 & 50.87 & 49.48 & 49.06 \\
\hline $\mathrm{Al}_{2} \mathrm{O}_{3}$ & 18.75 & 18.16 & 18.35 & 19.14 & 19.25 & 18.87 \\
\hline $\mathrm{CaO}$ & 5.27 & 5.05 & 5.05 & 5.34 & 5.48 & 5.27 \\
\hline $\mathrm{BaO}$ & 0.71 & 0.63 & 0.85 & 0.64 & 0.79 & 0.64 \\
\hline $\mathrm{K}_{2} \mathrm{O}$ & 12.55 & 13.76 & 13.11 & 10.42 & 12.52 & 12.96 \\
\hline $\mathrm{Na}_{2} \mathrm{O}$ & 0.61 & 0.56 & 0.44 & 0.60 & 0.78 & 0.67 \\
\hline $\mathrm{H}_{2} \mathrm{O}$ & 21.97 & 21.66 & 21.82 & 22.30 & 22.18 & 21.93 \\
\hline total & 109.31 & 108.49 & 108.96 & 109.31 & 110.48 & 109.40 \\
\hline $\mathrm{Si}^{4+}$ & 8.097 & 8.088 & 8.112 & 8.205 & 8.027 & 8.048 \\
\hline $\mathrm{Al}^{3+}$ & 3.618 & 3.557 & 3.567 & 3.638 & 3.681 & 3.649 \\
\hline $\mathrm{Ca}^{2+}$ & 0.925 & 0.899 & 0.919 & 0.923 & 0.952 & 0.927 \\
\hline $\mathrm{Ba}^{2+}$ & 0.045 & 0.041 & 0.054 & 0.041 & 0.051 & 0.041 \\
\hline $\mathrm{K}^{+}$ & 2.621 & 2.918 & 2.759 & 2.144 & 2.591 & 2.726 \\
\hline $\mathrm{Na}^{+}$ & 0.193 & 0.180 & 0.141 & 0.188 & 0.246 & 0.213 \\
\hline$\Sigma \mathrm{Ca}+\mathrm{Ba}+\mathrm{K}+\mathrm{Na}$ & 3.784 & 4.038 & 3.873 & 3.296 & 3.840 & 3.907 \\
\hline $\mathrm{H}_{2} \mathrm{O}$ & 12 & 12 & 12 & 12 & 12 & 12 \\
\hline $\mathrm{T}_{\mathrm{Si}}$ & 0.69 & 0.69 & 0.69 & 0.69 & 0.69 & 0.69 \\
\hline
\end{tabular}

Empirický vzorec byl přepočten na bázi 24 kyslíků. $\mathrm{H}_{2} \mathrm{O}$ bylo dopočítáno na základě teoretického obsahu $12 \mathrm{H}_{2} \mathrm{O}$. 
minerál chemicky homogenní. Při studiu jeho chemického složení (tab. 6) byly zjištěny obsahy $\mathrm{Si}, \mathrm{Al}, \mathrm{Ca}, \mathrm{Mg}, \mathrm{Sr}$ a K ; ostatní měřené prvky byly pod mezí detekce. Empirický vzorec offretitu (průměr šesti bodových analýz) je na bázi 36 kyslíků možno vyjádřit jako $\mathrm{K}_{202} \mathrm{Ca}_{131} \mathrm{Mg}_{032} \mathrm{Sr}_{0.09}\left(\mathrm{Al}_{5.42}\right.$ $\left.\mathrm{Si}_{12.56}\right) \mathrm{O}_{36} \cdot 16 \mathrm{H}_{2} \mathrm{O}$. Vedle $\mathrm{K}$, Ca a Mg byl v kationtové části molekuly zdejšího offretitu zjištěn zvýšený obsah $\mathrm{Sr}(0.06$ - 0.13 apfu). Zvýšené obsahy Sr mají též offretity ze Sasbachu v Německu (Passaglia et al. 1998) nebo z Poustevny u Nového Boru (Pauliš et al. 2019). Hodnota $T_{S i}=$ $\mathrm{Si} /(\mathrm{Si}+\mathrm{Al})=0.70$ studovaného offretitu je ve spodní části rozmezí uváděného pro tento minerální druh (Coombs et al. 1997).

Chabazit-K vytváří na Wachsteinu čiré, skelně lesklé klencové krystaly o velikosti 1 - $2 \mathrm{~mm}$, na trhlinách vulkanitu až $4 \mathrm{~mm}$. Často ve větších dutinách narůstá jako jediný zeolit na bělavou jílovou krustu. $V$ některých dutinách mají jeho klencové krystaly výrazně „tabulkovitý“ tvar. Často ho pokrývá čirý opál (obr. 11).
Rentgenová prášková data chabazitu-K z Wachsteinu (tab. 7) jsou blízká datům pro tento minerální druh, zpřesněné parametry jeho základní cely dobře odpovídají publikovaným údajům pro tento zeolit (tab. 8). V BSE obraze (obr. 12) byly rozlišeny dva typy chabazitu-K, které se liší minoritními obsahy Sr či Ba. Při studiu chemického složení chabazitu-K s obsahem Sr byly zjištěny obsahy $\mathrm{Si}, \mathrm{Al}, \mathrm{Ca}, \mathrm{Mg}, \mathrm{Sr}$ a $\mathrm{K}$; ostatní měřené prvky byly pod mezí detekce. Empirický vzorec tohoto chabazitu-K (tab. 9) (průměr pěti bodových analýz) je na bázi 24 kyslíků možno vyjádřit jako $\left(\mathrm{K}_{1.92} \mathrm{Ca}_{0.79} \mathrm{Mg}_{0.40} \mathrm{Sr}_{0.03}\right)_{\Sigma 3.14}$ $\left(\mathrm{Al}_{3.24} \mathrm{Si}_{8.49} \mathrm{O}_{24}\right) \cdot 12 \mathrm{H}_{2} \mathrm{O}$. Hodnota $\mathrm{T}_{\mathrm{Si}}=\mathrm{Si} /(\mathrm{Si}+\mathrm{Al})=0.72$ tohoto chabazitu je prí horní hranici rozmezí chabazitu-K (Coombs et al. 1997). Ve druhém chabazitu-K s obsahy Ba byly zjištěny obsahy $\mathrm{Si}, \mathrm{Al}, \mathrm{Ca}, \mathrm{Ba}, \mathrm{K}$ a Na; ostatní měřené prvky byly pod mezí detekce. Empirický vzorec tohoto chabazitu-K (tab. 10) (průměr pěti bodových analýz) je na bázi 24 kyslíků možno vyjádřit jako $\left(\mathrm{K}_{2.62} \mathrm{Ca}_{0.93}\right.$ $\left.\mathrm{Ba}_{0.05} \mathrm{Na}_{0.19}\right)_{\Sigma 3.79}\left(\mathrm{Al}_{3.62} \mathrm{Si}_{8.10} \mathrm{O}_{24}\right) \cdot 12 \mathrm{H}_{2} \mathrm{O}$. Hodnota $\mathrm{T}_{\mathrm{Si}}=\mathrm{Si} /$

Tabulka 11 Rentgenová prášková data phillipsitu-K z Wachsteinu

\begin{tabular}{|c|c|c|c|c|c|c|c|c|c|c|c|c|c|c|c|c|c|}
\hline$h$ & $k$ & I & $d_{o b s}$ & $I_{o b s}$ & $d_{\text {calc }}$ & $h$ & $k$ & I & $d_{o b s}$ & $I_{o b s}$ & $d_{\text {calc }}$ & $h$ & $k$ & 1 & $d_{o b s}$ & $l_{o b s}$ & $d_{\text {calc }}$ \\
\hline-1 & 0 & 0 & 8.149 & 11 & 8.137 & 2 & 4 & 0 & 2.687 & 17 & 2.687 & 0 & 8 & 1 & 1.7356 & $<1$ & 1.7362 \\
\hline 0 & 2 & 0 & 7.152 & 51 & 7.158 & -3 & 3 & 2 & 2.676 & 10 & 2.674 & -5 & 4 & 2 & 1.7209 & 3 & 1.7223 \\
\hline-1 & 1 & 1 & 7.122 & 55 & 7.105 & 1 & 2 & 2 & 2.5677 & 1 & 2.5671 & 4 & 0 & 1 & 1.7155 & 2 & 1.7159 \\
\hline 0 & 1 & 1 & 6.388 & 32 & 6.409 & 3 & 2 & 0 & 2.5345 & 1 & 2.5365 & 2 & 0 & 3 & 1.6810 & 4 & 1.6822 \\
\hline 1 & 2 & 0 & 5.347 & 4 & 5.375 & -4 & 0 & 2 & 2.4823 & 1 & 2.4814 & 4 & 2 & 1 & 1.6696 & $<1$ & 1.6686 \\
\hline 0 & 2 & 1 & 5.041 & 16 & 5.065 & -4 & 1 & 2 & 2.4440 & $<1$ & 2.4449 & -6 & 0 & 3 & 1.6557 & 4 & 1.6543 \\
\hline-2 & 0 & 1 & 4.967 & 15 & 4.963 & -1 & 3 & 3 & 2.3879 & 5 & 2.3884 & 2 & 8 & 0 & 1.6380 & 2 & 1.6380 \\
\hline-2 & 1 & 1 & 4.685 & 1 & 4.689 & -3 & 3 & 3 & 2.3734 & 1 & 2.3682 & 5 & 1 & 0 & 1.6168 & 1 & 1.6171 \\
\hline 1 & 0 & 1 & 4.298 & 10 & 4.295 & 3 & 3 & 0 & 2.3618 & $<1$ & 2.3581 & -6 & 2 & 3 & 1.6122 & $<1$ & 1.6118 \\
\hline 1 & 1 & 1 & 4.114 & 21 & 4.114 & -4 & 1 & 1 & 2.3113 & 1 & 2.3098 & -6 & & 2 & 1.5987 & 1 & 1.5997 \\
\hline-2 & 2 & 1 & 4.073 & 10 & 4.078 & 2 & 4 & 1 & 2.2495 & 1 & 2.2518 & -2 & 3 & 5 & 1.5928 & 1 & 1.5919 \\
\hline 2 & 0 & 0 & 4.066 & 7 & 4.069 & -4 & 2 & 1 & 2.2260 & 2 & 2.2246 & 1 & 1 & 4 & 1.5621 & $<1$ & 1.5618 \\
\hline-2 & 1 & 2 & 3.925 & 2 & 3.934 & 3 & 4 & 0 & 2.1623 & 1 & 2.1618 & -5 & & 4 & 1.5449 & 2 & 1.5462 \\
\hline 1 & 2 & 1 & 3.681 & 2 & 3.683 & -2 & 0 & 4 & 2.1581 & 1 & 2.1578 & -4 & 7 & 3 & 1.5434 & 3 & 1.5425 \\
\hline 0 & 1 & 2 & 3.469 & 3 & 3.477 & 2 & 1 & 2 & 2.1279 & $<1$ & 2.1239 & -6 & 0 & 4 & 1.5296 & $<1$ & 1.5289 \\
\hline-3 & 0 & 2 & 3.223 & 8 & 3.228 & 2 & 2 & 2 & 2.0551 & 2 & 2.0571 & -2 & 7 & 4 & 1.4844 & 2 & 1.4844 \\
\hline-1 & 3 & 2 & 3.197 & 100 & 3.201 & 3 & 5 & 0 & 1.9706 & 4 & 1.9691 & -6 & 4 & 4 & 1.4701 & 1 & 1.4713 \\
\hline-3 & 1 & 2 & 3.147 & 23 & 3.149 & -4 & 4 & 3 & 1.9640 & 5 & 1.9639 & 4 & 0 & 2 & 1.4487 & $<1$ & 1.4486 \\
\hline 2 & 3 & 0 & 3.092 & $<1$ & 3.096 & -5 & 2 & 3 & 1.8971 & 1 & 1.8975 & 0 & 1 & 5 & 1.4263 & 1 & 1.4264 \\
\hline-3 & 2 & 1 & 2.937 & 13 & 2.936 & 2 & 7 & 0 & 1.8279 & 3 & 1.8273 & -5 & 2 & 6 & 1.4018 & 1 & 1.4020 \\
\hline 2 & 0 & 1 & 2.896 & 2 & 2.897 & -3 & 6 & 3 & 1.7950 & 2 & 1.7959 & -7 & 2 & 4 & 1.3853 & 1 & 1.3852 \\
\hline 1 & 0 & 2 & 2.752 & 5 & 2.750 & 0 & 8 & 0 & 1.7903 & 6 & 1.7895 & -3 & 8 & 4 & 1.3818 & 2 & 1.3814 \\
\hline 1 & 1 & 2 & 2.701 & 13 & 2.701 & -5 & 2 & 4 & 1.7804 & 3 & 1.7795 & -5 & 7 & 4 & 1.3670 & 1 & 1.3667 \\
\hline-2 & 4 & 2 & 2.694 & 8 & 2.694 & -5 & 2 & 1 & 1.7717 & 8 & 1.7723 & -6 & 6 & 3 & 1.3595 & $<1$ & 1.3595 \\
\hline
\end{tabular}

Tabulka 12 Parametry základní cely phillipsitu (pro monoklinickou prostorovou grupu $P 2 / m$ )

\begin{tabular}{llllllll}
\hline & & $a[\AA]$ & $b[\AA]$ & $c[\AA]$ & $\beta\left[^{\circ}\right]$ & $V\left[\AA^{3}\right]$ \\
\hline phillipsit-K & Wachstein & tato práce & $9.926(3)$ & $14.316(3)$ & $8.763(2)$ & $124.93(1)$ & $1018.5(4)$ \\
phillipsit & Stráň & tato práce & $9.922(2)$ & $14.315(3)$ & $8.740(2)$ & $124.92(8)$ & $1017.9(4)$ \\
phillipsit-Ca & Poustevna & Pauliš et al. (2019) & $9.9206(19)$ & $14.315(3)$ & $8.7387(19)$ & $124.92(6$ & $1017.5(4)$ \\
Phillipsit-Ca & Zaječí vrch & Pauliš et al. (2019) & $9.9226(19)$ & $14.314(3)$ & $8.7396(17)$ & $124.92(5)$ & $1017.8(4)$ \\
phillipsit-Ca & Heřmanice & Pauliš et al. (2018b) & $9.922(19)$ & $14.314(4)$ & $8.742(18)$ & $124.91(3)$ & $1018.0(4)$ \\
phillipsit-K & Svor & Pauliš et al. (2016b) & $9.924(2)$ & $14.315(3)$ & $8.742(2)$ & $124.93(7)$ & $1018.2(4)$ \\
phillipsit-K & Vrbička & Pauliš et al. (2013) & $9.919(3)$ & $14.314(3)$ & $8.740(3)$ & $124.93(1)$ & $1017.5(6)$ \\
phillipsit-K & Nový Oldřichov & Pauliš et al. (2016a) & $9.925(1)$ & $14.312(3)$ & $8.740(2)$ & $124.92(3)$ & $1018.0(3)$ \\
phillipsit-Ca & Nový Oldřichov & Pauliš et al. (2016a) & $9.922(1)$ & $14.313(3)$ & $8.743(2)$ & $124.91(2)$ & $1018.1(3)$ \\
phillipsit & & Gatta et al. (2009) & $9.9238(6)$ & $14.3145(5)$ & $8.7416(5)$ & $124.920(9)$ & 1018.2 \\
phillipsit-Ca & Jehla & Pauliš et al. (2015) & $9.924(2)$ & $14.321(4)$ & $8.737(2)$ & $124.92(3)$ & $1017.4(4)$ \\
phillipsit-K & Hackenberg & Pauliš et al. (2014) & $9.917(4)$ & $14.314(8)$ & $8.737(4)$ & $124.92(0)$ & $1016.9(9)$ \\
\hline
\end{tabular}


$(\mathrm{Si}+\mathrm{Al})=0.69$ tohoto chabazitu se nachází též $v$ horní hranici rozmezí uváděného pro chabazit-K (Coombs et al. 1997).

Phillipsit-K je na Wachsteinu vzácnější, tvoří drobné bezbarvé sloupečkovité krystaly o velikosti do $1 \mathrm{~mm}$ a polokulovité agregáty o průměru do $2 \mathrm{~mm}$, vystupující v asociaci s offretitem a chabazitem-K.

Rentgenová prášková data phillipsitu-K z Wachsteinu (tab. 11) jsou blízká datům pro tento minerální druh, zpřesněné parametry jeho základní cely jsou v tabulce 12 porovnány s publikovanými údaji. V BSE obraze je studovaný minerál chemicky homogenní. Při studiu chemického složení byly zjištěny obsahy $\mathrm{Si}, \mathrm{Al}, \mathrm{Ca}, \mathrm{Ba}, \mathrm{K}$ a Na; ostatní měřené prvky byly pod mezí detekce. Empirický vzorec tohoto phillipsitu-K (tab. 13; průměr pěti bodových analýz) je možné vyjádřit jako $\left(\mathrm{K}_{3.06} \mathrm{Ca}_{1.06} \mathrm{Na}_{0.17} \mathrm{Ba}_{0.04}\right)_{\Sigma 4.32}$ $\left(\mathrm{Al}_{4.98} \mathrm{Si}_{10.91} \mathrm{O}_{32}\right) \cdot 12 \mathrm{H}_{2} \mathrm{O}$. Obsah Ca je oproti $\mathrm{K}$ zhruba třetinový, Ba je obsaženo ve velmi nízké koncentraci (0.03 - $0.06 \mathrm{apfu})$. Hodnota $\mathrm{T}_{\mathrm{Si}}=\mathrm{Si} /(\mathrm{Si}+\mathrm{Al})=0.69$ tohoto phillipsitu je ve střední části uváděného rozmezí (Coombs et al. 1997).

\section{Lokalita Klučky - Strán̆}

Lokalita Klučky - Stráň se nachází na strmém svahu jihovýchodně od vrcholu Klučky, těsně nad udržovanou makadamovou lesní cestou (GPS: $50^{\circ} 46$ '39.88“ N; 14³1'10.52“ E). Celý svah je tvořen pyroklastiky, místy $s$ velice hojným, jemně krystalovaným offretitem ve tmelu (obr. 13, 14)

Vedle pyroklastik jsou ve výchozech prítomny bazaltické horniny narudle tmavohnědé barvy, kterým výrazná dutinatost propůjčuje klamný „melafyrový" vzhled. Dutiny o délce až přes $10 \mathrm{~mm}$ jsou silně protáhlé a subparalelně orientované. Objemově zaujímaji téměř čtvrtinu horniny. Místy obsahují na svých stěnách modravě bílé minerální povlaky. Vlastní hmota horniny je jen velmi slabě porfyrická, sporadické a špatně makroskopicky zřetelné vyrostlice $\mathrm{v}$ ní dosahují rozměru maximálně 0.5 $\mathrm{mm}$. Všesměrná, magmatickou fluidálností nepostižená základní hmota má zrnitost značně pod prahem makroskopické rozlišitelnosti. Mikroskopický obraz této horniny potvrzuje její slabou porfyričnost. Drobné vyrostlice klinopyroxenu a olivínu, altera- cemi jen slabě postiženému, rozhodně nejsou jeho markantem, hornina má skoro afyrickou povahu. $V$ její hmotě dominují hojné drobné plagioklasové lišty a rovněž drobný, převážně krátce prizmatický až izometricky zrnitý klinopyroxen. Toto základní minerální složení doplňují v podílu do 10 \% izometrická zrna magnetitu. Sporadicky se uplatňují xenomorfní zrna bezbarvého nízkodvojlomného až izotropního minerálu, jímž může být nefelín a/nebo analcim. Vulkanické sklo to však zřejmě není. Struktura horniny je velmi slabě porfyrická až afyrická, pilotaxitická, textura je silně dutinatá, paralelní. Jde o bazalt se slabou tefritickou afinitou.

Po petrografické stránce jsou zajímavé především zdejší vulkanické brekcie s hojnými zeolity, které Ize zařadit $k$ téměř bezplagioklasovým foiditům. Tyto brekcie mohly vzniknout jako závěrečný výbuchový produkt alkáliemi obohaceného zbytkového magmatu. Tyto horniny jsou tvořeny čokoládově hnědými úlomky zjevně alterovaného vulkanitu, jejichž tvar je nepravidelně drobtovitý, většinově ostrohranný a rozměry kolísají v rozpětí od 0.5 do $2 \mathrm{~cm}$. Tyto vulkanické „broky“" jsou tmeleny bohatě vě-
Tabulka 13 Chemické složení phillipsitu-K z Wachsteinu (hm. \%)

\begin{tabular}{lrrrrrr}
\hline & mean & 1 & 2 & 3 & 4 & 5 \\
\hline $\mathrm{SiO}_{2}$ & 53.19 & 52.48 & 53.39 & 53.45 & 52.75 & 53.88 \\
$\mathrm{Al}_{2} \mathrm{O}_{3}$ & 20.61 & 20.59 & 19.46 & 21.79 & 20.60 & 20.59 \\
$\mathrm{CaO}$ & 4.80 & 4.51 & 4.11 & 4.91 & 4.86 & 5.59 \\
$\mathrm{BaO}$ & 0.53 & 0.39 & 0.51 & 0.43 & 0.52 & 0.78 \\
$\mathrm{~K}_{2} \mathrm{O}$ & 11.71 & 11.75 & 14.36 & 9.90 & 11.41 & 11.14 \\
$\mathrm{Na}_{2} \mathrm{O}$ & 0.42 & 0.38 & 0.57 & 0.45 & 0.25 & 0.46 \\
$\mathrm{H}_{2} \mathrm{O}$ & 17.55 & 17.34 & 17.48 & 17.72 & 17.41 & 17.77 \\
\hline total & 108.81 & 107.44 & 109.88 & 108.65 & 107.80 & 110.21 \\
\hline $\mathrm{Si}^{4+}$ & 10.906 & 10.890 & 10.988 & 10.852 & 10.901 & 10.911 \\
$\mathrm{Al}^{3+}$ & 4.980 & 5.035 & 4.721 & 5.214 & 5.016 & 4.913 \\
$\mathrm{Ca}^{2+}$ & 1.055 & 1.003 & 0.906 & 1.069 & 1.076 & 1.213 \\
$\mathrm{Ba}^{2+}$ & 0.043 & 0.031 & 0.041 & 0.034 & 0.042 & 0.062 \\
$\mathrm{~K}^{+}$ & 3.063 & 3.110 & 3.769 & 2.564 & 3.007 & 2.876 \\
$\mathrm{Na}^{+}$ & 0.168 & 0.152 & 0.228 & 0.178 & 0.099 & 0.180 \\
\hline$\Sigma \mathrm{Ca}+\mathrm{Ba}+\mathrm{Na}+\mathrm{K}$ & 4.329 & 4.296 & 4.944 & 3.845 & 4.224 & 4.331 \\
\hline $\mathrm{H}_{2} \mathrm{O}$ & 12 & 12 & 12 & 12 & 12 & 12 \\
$\mathrm{~T}_{\mathrm{Si}}$ & 0.69 & 0.68 & 0.70 & 0.68 & 0.68 & 0.69 \\
\hline
\end{tabular}

Empirický vzorec byl přepočten na bázi 32 kyslíků. $\mathrm{H}_{2} \mathrm{O}$ bylo dopočítáno na základě teoretického obsahu $12 \mathrm{H}_{2} \mathrm{O}$.

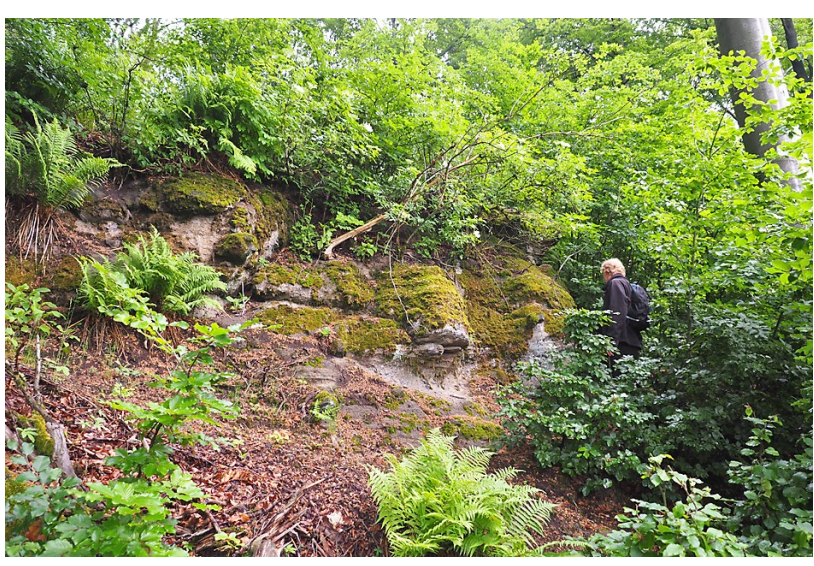

Obr. 13 Skalní výchozy na lokalitě Klučky - Stráň, foto P. Pauliš, 2020.

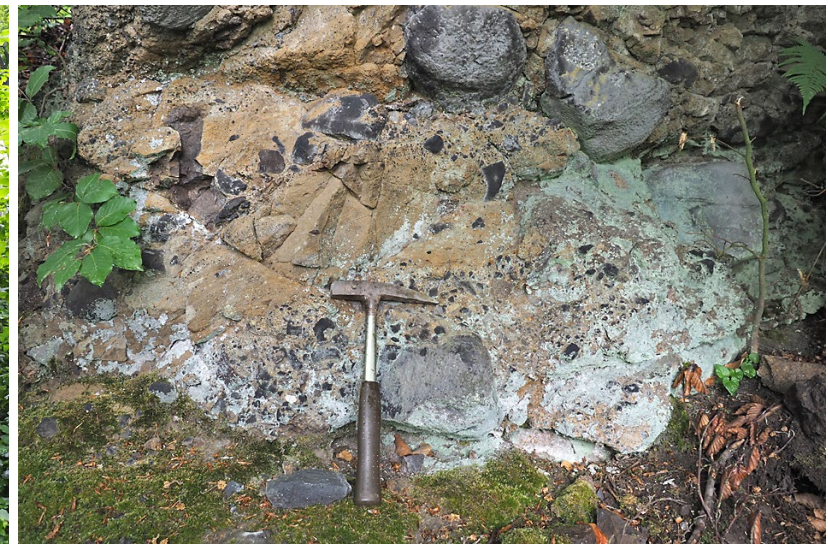

Obr. 14 Výchoz vulkanické brekcie na lokalitě Klučky Stráň, foto P. Pauliš, 2020. 


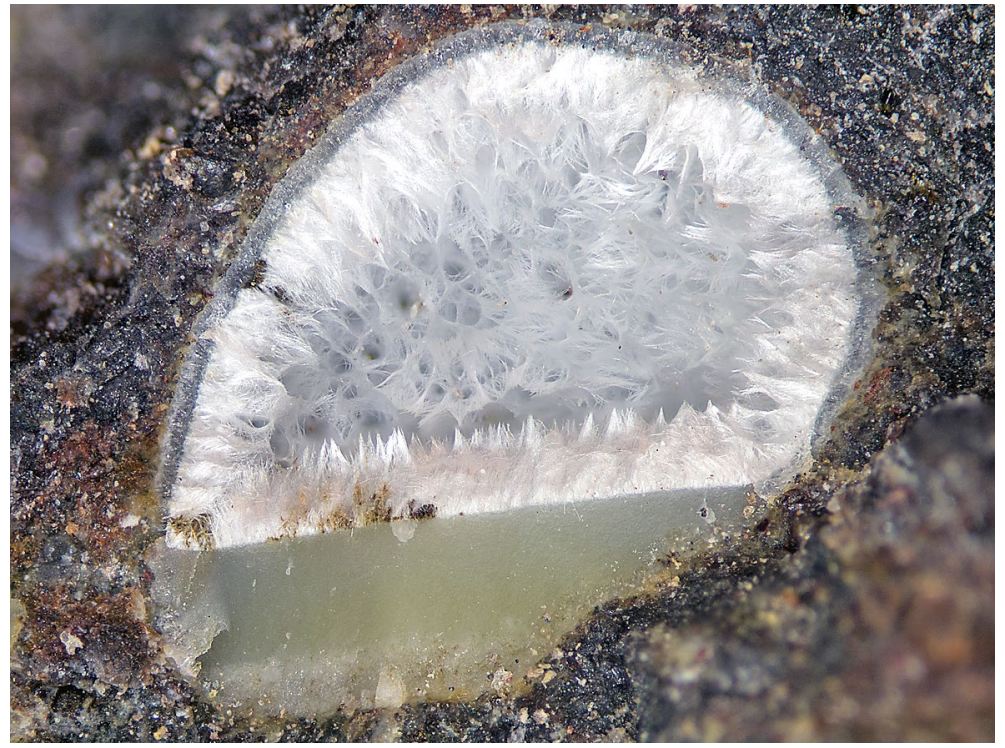

Obr. 15 Offretit z lokality Klučky - Stráň; šířka záběru $3 \mathrm{~mm}$, foto P. Fuchs.

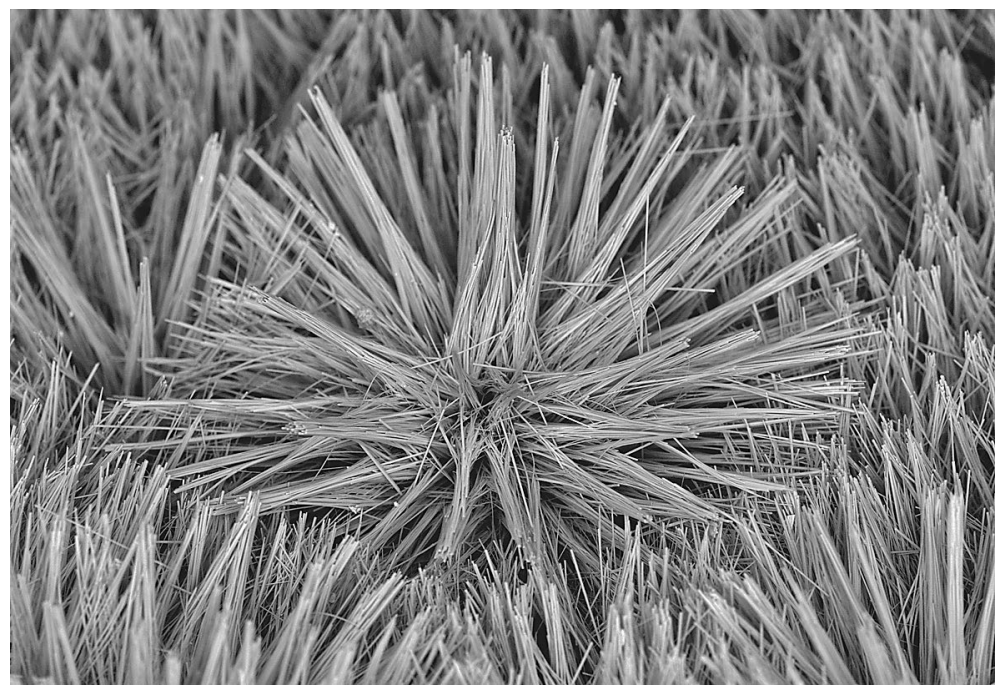

Obr. 16 Agregáty tvořené jemně jehlicovitými krystaly offretitu z lokality Klučky - Stráň; šiřka záběru $0.7 \mathrm{~mm}$, BSE foto B. Ekrt.

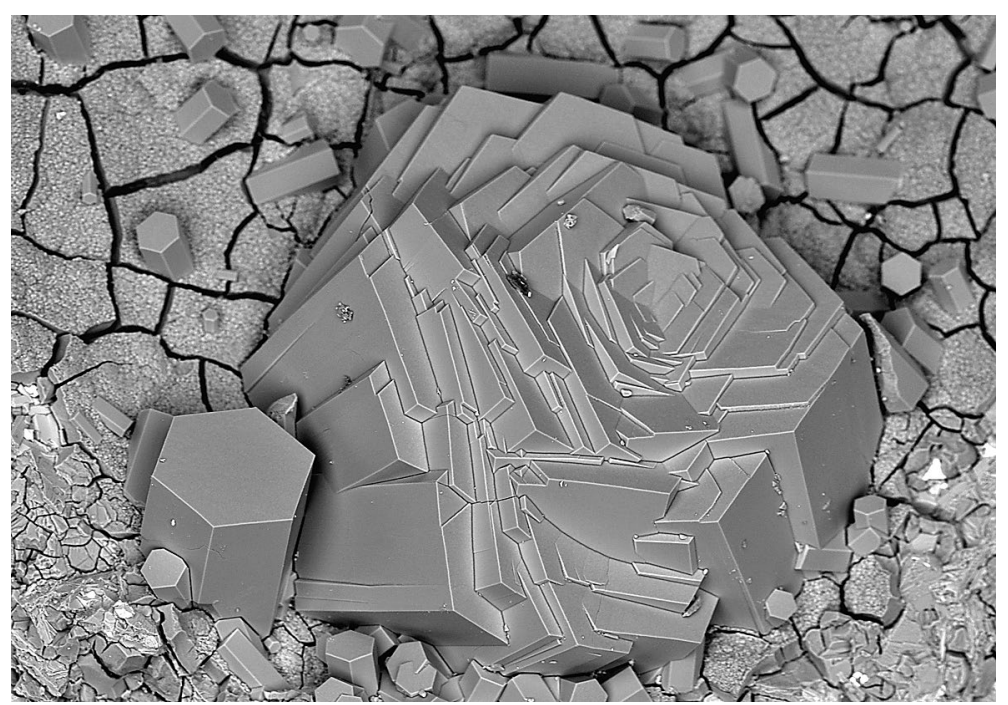

Obr. 17 Růžicový agregát offretitu z lokality Klučky - Stráň; šířka záběru $0.8 \mathrm{~mm}$, BSE foto B. Ekrt. tveným a tlustým sítivem bílé barvy, tvořeným hustými agregáty jemně jehličkovitého zeolitu. Jeho kvantitativní podíl na celkovém horninovém objemu přesahuje jednu třetinu. Uspořádání obou horninových složek, úlomků a zeolitové sítě, Ize označit jako chaotické a totéž označení vystihuje i mechanickým roztlukem vyvolaný rozpad horniny. Mikroskopické studium vykazuje pro vulkanické úlomky absenci vyrostlic pyroxenu i olivínu. Horninu tvoří jemnozrnný holokrystalický agregát složený převážně z mikrosloupečkovitého klinopyroxenu a $z$ abnormálně velkého množství zrn magnetitu (až 15 \% hmoty), často automorfně omezeného. Olivín chybí. Jako další podstatná složka vystupuje xenomorfní mesostázový světlý silikát, patřící bud' nefelínu nebo analcimu, nejspíše však oběma. Plagioklasové mikrolišty jsou zastoupeny jen minoritně. Tmelové sítivo patří jehličkám zeolitového minerálu. Struktura úlomků vulkanické horniny je afyricky holokrystalicky mikrozrnitá, textura horniny jako celku je velmi výrazně brekciovitá.

Vulkanické úlomky lze klasifikovat jako afyrický bezolivinický analcimicko-nefelinický foidit s velmi slabou tefritickou tendencí, magnetitem bohatý.

Brekcie je tvořena výše popsanými pestrými vulkanogenními horninami, přičemž prostory mezi úlomky vulkanitů jsou vyplněny (nebo povlečeny) souvislou krustou bělavých, jemně vláknitých až plstnatých krystalů offretitu délky do 0.5 až $0.7 \mathrm{~mm}$. Mocnost krusty offretitu ale často nepřesahuje $0.2 \mathrm{~mm}$. Velikost polygonálních dutin mezi úlomky vulkanitů se běžně pohybuje kolem $1 \mathrm{~cm}$, výjimečné nejsou dutiny velikosti $2-3 \mathrm{~cm}$. Offretit někdy vytvárí radiálně paprsčité shluky jednotlivě vyvinutých jehliček či hemisférické agregáty. Běžně se v dutinkách vyskytují jednotlivě vyvinuté, dokonale čiré, skelně lesklé klencové krystaly chabazitu a jejich prorostlice velikosti až 1 mm. Zvláštností aglomerátu jsou zaoblená, velmi světle zelená, průhledná zrna olivínu dosahující velikosti kolem $5 \mathrm{~mm}$. Nejzajímavější vzorky offretitu a dalších zeolitů poskytly 0.3 - $1 \mathrm{~m}$ velké bloky celistvého čerstvého vulkanitu plovoucí v konglomerátu, zvláště jejich cca $15 \mathrm{~cm}$ silný lem s hojnými čočkovitými dutinami, jejichž délka dosahuje až 4 $\mathrm{cm}$, vzácně i více. Dutiny vystlané jemným filmem jílového minerálu obsahuji řadu různých krystalových forem offretitu a jejich agregátů připomínající výskyty ze Zaječího vrchu u Nového Boru a Poustevny u Polevska (Pauliš et al. 2019), které doprovázejí chabazit a phillipsit. Směrem dovnitř bloků offretit $v$ dutinách rychle mizí, zůstávají jen phillipsit a chabazit.

Nejběžnější morfologickou formou offretitu v dutinách je souvislá kůra (obr. 15) tvořená bělavými, jemně vláknitými až plstnatými krystaly jako v brekcii (obr. 16). Vzácně tvoří základní jílovitý pokryv dutin krápníčky, 
které offretit bud' zcela obrůstá, nebo jen vytváří štětičky na jejich konci. Zajímavé jsou jednotlivé, dobře vyvinuté, ostrohranné, šestiboké, tlustě sloupečkovité krystaly a jejich růžicovité prorostlice dosahující průměru kolem $1 \mathrm{~mm}$ (obr. 17). $V$ některých dutinách jsou přitomné agregáty offretitu, složené z prorostlých diskovitých útvarů s krátce příčně sloupečkovou stavbou (obr. 18), připomínající vzorky z Vogelsbergu (Betz 2019). Vzácnější jsou kůry offretitu složené $z$ dlouze sloupečkovitých šestibokých krystalů o délce až $1 \mathrm{~mm}$, hřebenovitě ukončených.

Rentgenová prášková data offretitu z lokality Klučky - Stráň (tab. 14) jsou blízká datům pro tento minerální druh, zpřesněné parametry jeho základní cely jsou $v$ tabulce 5 porovnány s publikovanými údaji. $V$ BSE obraze je studovaný minerál chemicky homogenní. Při studiu jeho chemického složení (tab. 15) byly zjištěny obsahy $\mathrm{Si}, \mathrm{Al}, \mathrm{Ca}, \mathrm{Mg}, \mathrm{Sr}, \mathrm{K}$ a Na; ostatní měřené prvky byly pod mezí detekce. Empirický vzorec offretitu (průměr šesti bodových analýz) je na bázi 36 kyslíků možno vyjádřit jako
$\mathrm{Ca}_{1.48} \mathrm{~K}_{1.02} \mathrm{Mg}_{0.59} \mathrm{Na}_{0.10} \mathrm{Sr}_{0.09}\left(\mathrm{Al}_{5.56} \mathrm{Si}_{12.52}\right) \mathrm{O}_{36} \cdot 16 \mathrm{H}_{2} \mathrm{O}$. Oproti offretitu $\mathrm{z}$ Wachsteinu u něho převažuje $\mathrm{Ca}$ nad $\mathrm{K}$ a zjištěny byly i minoritní obsahy $\mathrm{Na}(0.01-0.26$ apfu). Hodnota $\mathrm{T}_{\mathrm{Si}}=\mathrm{Si} /(\mathrm{Si}+\mathrm{Al})=0.69$ tohoto offretitu je ve spodní části rozmezí uváděného pro tento minerální druh (Coombs et al. 1997).

Chabazit-K se $v$ dutinách běžně vyskytuje $v$ podobě klencových, dokonale čirých, skelně lesklých, jednotlivě vyvinutých krystalů a jejich prorostlic, vzácněji fakolitů, o velikosti 1 až $2 \mathrm{~mm}$, narůstajících jednotlivě na offretit nebo jemnou bělavou jílovou krustu. Offretit někdy chabazit epitaxně porůstá, přičemž na hrubě srostlých fakolitech ze tř́ klencových jedinců vytváří charakteristický obraz písmene „W“ (obr. 19, 20) s tenkou bezbarvou středovou zónou a delším bělavým oboustranným ukončením jehlic. Offretitové jehlice někdy jednotlivě naplocho narůstají na povrch chabazitových krystalů.

Rentgenová prášková data chabazitu-K z lokality Klučky - Stráň (tab. 16) jsou blízká datům uváděným pro

Tabulka 14 Rentgenová prášková data offretitu ze Stráně

\begin{tabular}{rrrrrrrrrrrrrrrrrr}
\hline$h$ & $k$ & $l$ & $d_{o b s}$ & $l_{o b s}$ & $d_{c a l c}$ & $h$ & $k$ & $l$ & $d_{o b s}$ & $l_{o b s}$ & $d_{c a l c}$ & $h$ & $k$ & $l$ & $d_{o b s}$ & $l_{\text {obs }}$ & $d_{c a l c}$ \\
\hline 0 & 1 & 0 & 11.539 & 100 & 11.527 & 0 & 4 & 1 & 2.694 & 1 & 2.694 & 1 & 6 & 0 & 1.7585 & 1 & 1.7579 \\
1 & 1 & 0 & 6.663 & 4 & 6.655 & 2 & 3 & 0 & 2.645 & 1 & 2.645 & 0 & 6 & 2 & 1.7125 & 1 & 1.7140 \\
0 & 1 & 1 & 6.384 & 1 & 6.338 & 1 & 4 & 0 & 2.5163 & 12 & 2.5154 & 4 & 4 & 0 & 1.6639 & 3 & 1.6638 \\
0 & 2 & 0 & 5.769 & 51 & 5.764 & 2 & 3 & 1 & 2.4967 & $<1$ & 2.4972 & 3 & 5 & 0 & 1.6476 & $<1$ & 1.6467 \\
0 & 2 & 1 & 4.589 & 1 & 4.590 & 0 & 5 & 0 & 2.3069 & 2 & 2.3054 & 2 & 6 & 0 & 1.5989 & 1 & 1.5985 \\
1 & 2 & 0 & 4.359 & 33 & 4.357 & 3 & 3 & 0 & 2.2191 & 4 & 2.2184 & 1 & 6 & 2 & 1.5949 & 1 & 1.5950 \\
0 & 3 & 0 & 3.843 & 36 & 3.842 & 2 & 4 & 0 & 2.1788 & $<1$ & 2.1784 & 0 & 6 & 3 & 1.5282 & $<1$ & 1.5299 \\
1 & 2 & 1 & 3.778 & 5 & 3.778 & 3 & 3 & 1 & 2.1298 & $<1$ & 2.1293 & 4 & 5 & 0 & 1.4755 & $<1$ & 1.4759 \\
0 & 1 & 2 & 3.602 & $<1$ & 3.604 & 0 & 3 & 3 & 2.1152 & $<1$ & 2.1128 & 2 & 6 & 2 & 1.4729 & $<1$ & 1.4731 \\
0 & 3 & 1 & 3.427 & $<1$ & 3.428 & 2 & 4 & 1 & 2.0935 & 1 & 2.0939 & 3 & 3 & 4 & 1.4417 & $<1$ & 1.4418 \\
2 & 2 & 0 & 3.327 & 4 & 3.328 & 1 & 5 & 0 & 2.0710 & $<1$ & 2.0704 & 4 & 4 & 3 & 1.3901 & $<1$ & 1.3901 \\
1 & 3 & 0 & 3.190 & 2 & 3.197 & 1 & 5 & 1 & 1.9971 & 1 & 1.9974 & 4 & 5 & 2 & 1.3760 & $<1$ & 1.3755 \\
1 & 3 & 1 & 2.946 & 1 & 2.946 & 0 & 5 & 2 & 1.9698 & $<1$ & 1.9703 & 0 & 6 & 4 & 1.3504 & $<1$ & 1.3499 \\
0 & 4 & 0 & 2.883 & 49 & 2.882 & 2 & 5 & 0 & 1.8459 & 1 & 1.8458 & 1 & 8 & 0 & 1.3472 & $<1$ & 1.3492 \\
1 & 2 & 2 & 2.860 & 2 & 2.861 & 1 & 4 & 3 & 1.7841 & $<1$ & 1.7836 & & & & & \\
\hline
\end{tabular}

Tabulka 15 Chemické složení offretitu ze Stráně (hm. \%)

\begin{tabular}{|c|c|c|c|c|c|c|c|}
\hline & mean & 1 & 2 & 3 & 4 & 5 & 6 \\
\hline $\mathrm{SiO}_{2}$ & 51.67 & 50.41 & 54.70 & 51.47 & 52.83 & 50.57 & 50.06 \\
\hline $\mathrm{Al}_{2} \mathrm{O}_{3}$ & 19.48 & 19.63 & 17.67 & 19.62 & 19.37 & 20.16 & 20.40 \\
\hline $\mathrm{MgO}$ & 1.62 & 1.40 & 2.63 & 1.34 & 1.41 & 1.30 & 1.65 \\
\hline $\mathrm{CaO}$ & 5.68 & 6.23 & 3.89 & 6.16 & 5.76 & 6.17 & 5.89 \\
\hline $\mathrm{SrO}$ & 0.66 & 0.84 & 0.09 & 0.56 & 0.72 & 0.87 & 0.86 \\
\hline $\mathrm{K}_{2} \mathrm{O}$ & 3.30 & 3.22 & 2.85 & 3.56 & 3.35 & 3.30 & 3.51 \\
\hline $\mathrm{Na}_{2} \mathrm{O}$ & 0.21 & 0.21 & 0.02 & 0.39 & 0.02 & 0.06 & 0.56 \\
\hline $\mathrm{H}_{2} \mathrm{O}$ & 19.80 & 19.59 & 20.07 & 19.88 & 20.09 & 19.72 & 19.84 \\
\hline total & 102.42 & 101.52 & 101.92 & 103.48 & 103.65 & 102.15 & 102.77 \\
\hline $\mathrm{Si}^{4+}$ & 12.518 & 12.341 & 13.073 & 12.419 & 12.615 & 12.300 & 12.106 \\
\hline $\mathrm{Al}^{3+}$ & 5.564 & 5.665 & 4.977 & 5.579 & 5.452 & 5.779 & 5.815 \\
\hline $\mathrm{Mg}^{2+}$ & 0.585 & 0.511 & 0.938 & 0.481 & 0.502 & 0.471 & 0.594 \\
\hline $\mathrm{Ca}^{2+}$ & 1.475 & 1.635 & 0.997 & 1.592 & 1.473 & 1.608 & 1.526 \\
\hline $\mathrm{Sr}^{2+}$ & 0.093 & 0.119 & 0.013 & 0.078 & 0.099 & 0.123 & 0.121 \\
\hline $\mathrm{K}^{+}$ & 1.019 & 1.006 & 0.870 & 1.096 & 0.935 & 1.023 & 1.084 \\
\hline $\mathrm{Na}^{+}$ & 0.099 & 0.100 & 0.009 & 0.183 & 0.009 & 0.029 & 0.261 \\
\hline$\Sigma \mathrm{Mg}+\mathrm{Ca}+\mathrm{Sr}+\mathrm{K}+\mathrm{Na}$ & 3.271 & 3.371 & 2.827 & 3.430 & 3.018 & 3.254 & 3.586 \\
\hline $\mathrm{H}_{2} \mathrm{O}$ & 16 & 16 & 16 & 16 & 16 & 16 & 16 \\
\hline $\mathrm{T}_{\mathrm{Si}}$ & 0.69 & 0.69 & 0.72 & 0.69 & 0.70 & 0.68 & 0.68 \\
\hline
\end{tabular}

Empirický vzorec byl přepočten na bázi 36 kyslíků. $\mathrm{H}_{2} \mathrm{O}$ bylo dopočítáno na základě teoretického obsahu $16 \mathrm{H}_{2} \mathrm{O}$. 


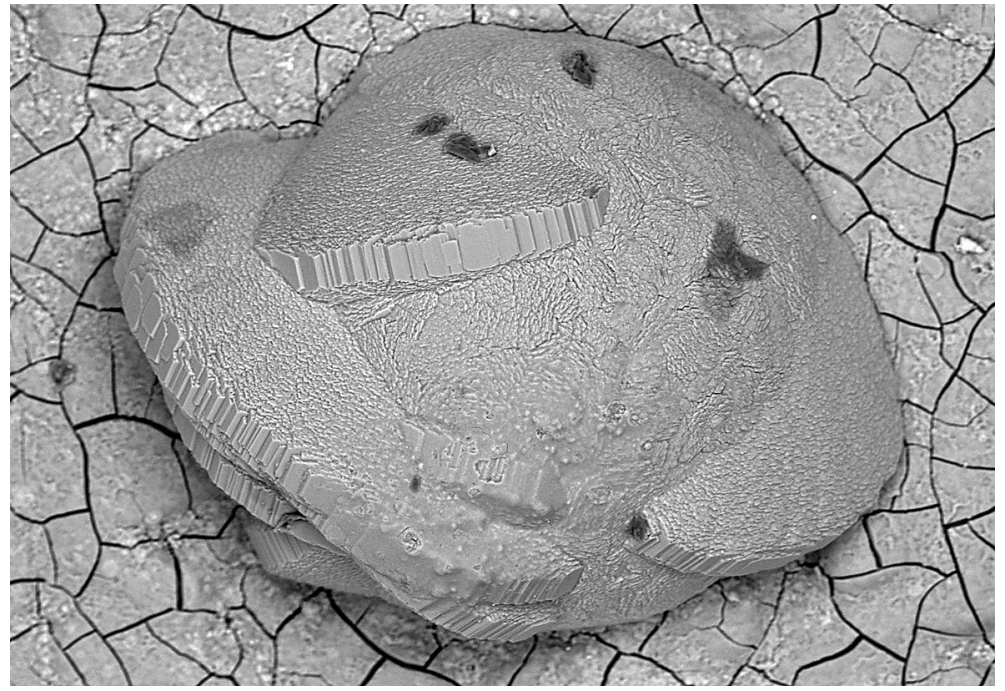

Obr. 18 Agregát offretitu ve tvaru prorůstajících se disků z lokality Klučky - Strán̆; šírka záběru $0.5 \mathrm{~mm}$, BSE foto B. Ekrt.

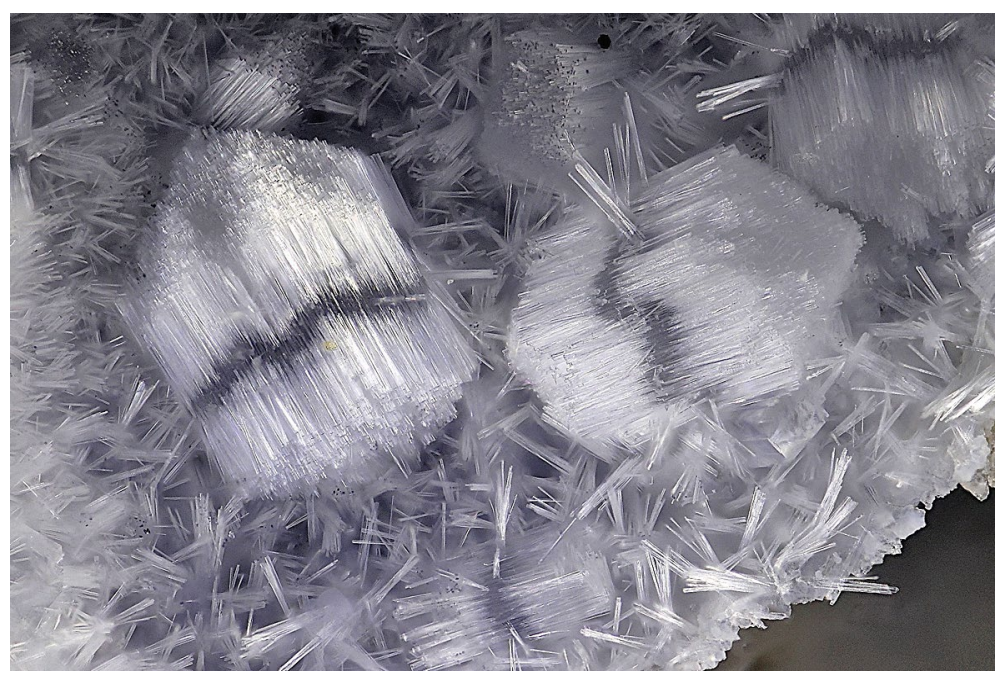

Obr. 19 Nárůsty offretitu na chabazitu (fakolitu) z lokality Klučky - Stráň; šírka záběru $2 \mathrm{~mm}$, foto $\mathrm{V}$. Betz.

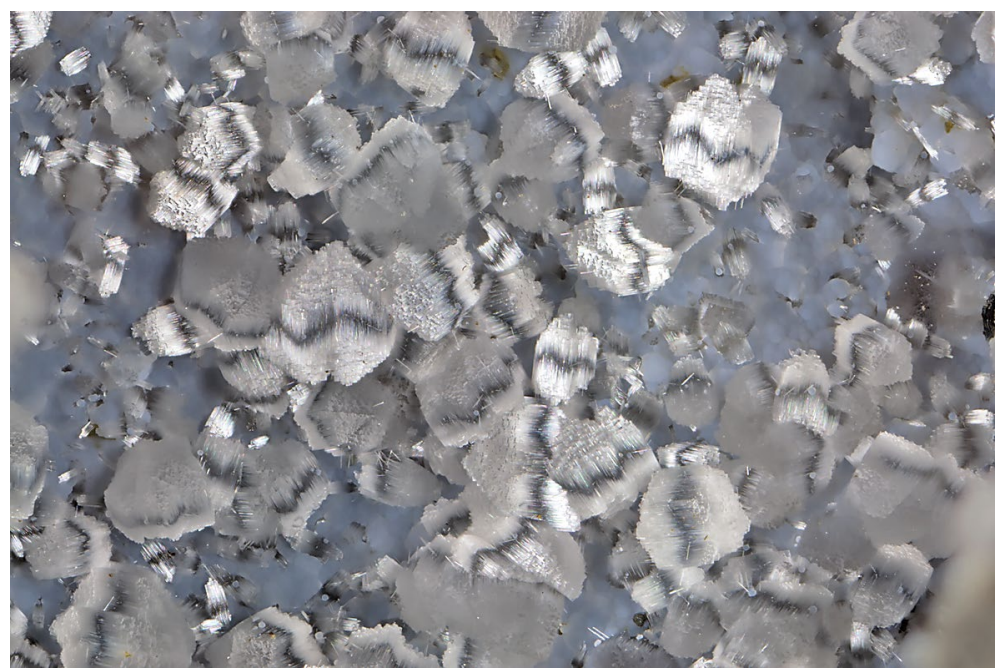

Obr. 20 Zákonité nárůsty offretitu na chabazitu (fakolitu) z lokality Klučky - Stráň; šířka záběru $4 \mathrm{~mm}$, foto $B$. Bureš. tento minerální druh, zpřesněné parametry jeho základní cely dobře odpovídají publikovaným údajům pro tento zeolit (tab. 8). V BSE obraze je chabazit-K chemicky homogenní. Při studiu jeho chemického složení (tab. 17) byly zjištěny obsahy $\mathrm{Si}, \mathrm{Al}, \mathrm{Ca}, \mathrm{Mg}$, $\mathrm{K}$ a Na; ostatní měřené prvky byly pod mezí detekce. Empirický vzorec tohoto chabazitu -K (průměr pěti bodových analýz) je na bázi 24 kyslíků možno vyjádřit jako $\left(\mathrm{K}_{1.06} \mathrm{Mg}_{0.70}\right.$ $\left.\mathrm{Ca}_{051}\right)_{\Sigma 2.27}\left(\mathrm{Al}_{27} \mathrm{Si}_{8.96} \mathrm{O}_{24}\right) \cdot 12 \mathrm{H}_{2} \mathrm{O}$. Hodnota $\mathrm{T}_{\mathrm{Si}}$ $=\mathrm{Si} /(\mathrm{Si}+\mathrm{Al})=0.76$ tohoto chabazitu je pri horní hranici uváděného rozmezí (Coombs et al. 1997).

Phillipsit se $v$ dutinách vyskytuje rovněž běžně, tvoří souvislou kưru z krátce sloupečkovitých bezbarvých krystalů nebo jednotlivé, dobře vyvinuté sloupečkovité krystaly o délce 1 - 2 mm, vzácně vystupuje i v sendvičových agregátech podobných lokalitě Klučky - Parkoviště.

Rentgenová prášková data phillipsitu z lokality Klučky - Stráň (tab. 18) jsou blízká datům uváděným pro tento minerální druh, zpřesněné parametry jeho základní cely jsou v tabulce 12 porovnány s publikovanými údaji. $V$ BSE obraze je phillipsit chemicky homogenní. Při studiu jeho chemického složení byly zjištěny obsahy $\mathrm{Si}, \mathrm{Al}, \mathrm{Ca}, \mathrm{Sr}$, $\mathrm{Ba}, \mathrm{K}$ a Na; ostatní měřené prvky byly pod mezí detekce. Jeho empirický vzorec K (tab. 19; průměr čtyř bodových analýz) je možné vyjádřit jako $\left(\mathrm{K}_{1.78} \mathrm{Ca}_{1.61} \mathrm{Na}_{0.21} \mathrm{Ba}_{0.08} \mathrm{Sr}_{0.02}\right)_{\Sigma 3.70}$ $\left(\mathrm{Al}_{5.10} \mathrm{Si}_{10.82} \mathrm{O}_{32}\right) \cdot 12 \quad \mathrm{H}_{2} \mathrm{O}$. V kationtové části jsou zastoupeny $\mathrm{K}$ i Ca približně ve stejném množství, část bodových analýz odpovídá phillipsitu-K, druhá pak jeho Ca-dominantnímu členu. Oproti phillipsitu-K z Wachsteinu obsahuje cca dvakrát větší obsah Ba a malé množství Sr (0.01 - 0.04 apfu). Hodnota $\mathrm{T}_{\mathrm{Si}}$ $=\mathrm{Si} /(\mathrm{Si}+\mathrm{Al})=0.68$ tohoto phillipsitu je ve střední části rozmezí uváděného pro tento minerální druh (Coombs et al. 1997).

\section{Lokalita Klučky - Parkoviště}

Lokalita se nachází na udržované lesní cestě (totožná s lokalitou Klučky - Stráň), východně od vrcholu Klučky, v místě, kde bylo lesní správou na cestě vytvořeno malé parkoviště (GPS: $50^{\circ} 466^{\prime 4} 45.10^{\prime \prime} \mathrm{N}$; $14^{\circ} 31^{\prime} 33.46^{\prime \prime}$ E). Nepř́iliš rozsáhlé zemní práce zasáhly do svahu a v hlinité svahové suti byl vytvořen plošně malý, několik metrů vysoký zářez (obr. 21). Vyhrnutá svahová hlína s řídkými plovoucími bločky vulkanitů byla přesunuta na druhou stranu cesty, na jižní svah hřbetu. Zdánlivě mineralogicky málo nadějná lokalita však poskytla mimořádné zajímavé ukázky zeolitové mineralizace, především epitaxních nárůstů offretitu na chabazitu a neobvykle vyvinutých krystalů phillipsitu. Některé $z$ až $70 \mathrm{~cm}$ velkých balvanů vulkanitů ze svahovin byly hodně dutinaté. $V$ protáhlých čočkovitých dutinách až $8 \mathrm{~cm}$ dlouhých byla zjištěna asociace offretit - chabazit phillipsit. 
Nejzajímavějším minerálem je zde offretit, který se tu vyskytuje ve vícegeneračních agregátech různých typů, a to i v jedné dutině. Nejčastěji vytváŕí bezbarvou souvislou ledvinitou krustu mocnosti $0 . X \mathrm{~mm}$, složenou $\mathrm{z}$ radiálních agregátů štíhlých, dokonale průhledných sloupečkovitých krystalů ukončených plochou báze. Jednotlivé snopečky, narůstající prímo na stěny dutiny, jsou od sebe odděleny jemnou žlutavou krustou. Při pohledu shora tak krusta vypadá jako medová plástev. Někdy jsou agregáty offretitu pokryté tenkou čirou vrstvičkou druhotného opálu. Offretit může tvořit i jednotlivě vyvinuté snopkové agregáty narůstající prímo na stěny dutin, přičemž prostor mezi nimi je pokryt rozpraskanou vrstvičkou jílového minerálu. Agregáty offretitu pak mají oproti světlé jílové kůře tmavou barvu způsobenou prosvítáním černošedé stěny podložky.

Chabazit tvoří v dutinkách drobné čiré klencové krystaly 1 až $3 \mathrm{~mm}$ velké, fakolitová dvojčata i zajímavé polokulovité agregáty o průměru až $3 \mathrm{~mm}$ (obr. 22). Klencové krystaly chabazitu bývají často epitaxiálně obrostlé offre- titem, vzorky mají podobný vzhled jako vzorky z Nového Oldřichova - nádraží (Pauliš et al. 2016a). Epitaxní nárůsty na chabazitu jsou obvykle tvořeny velice tenkou souvislou vrstvičkou jemných šestibokých jehličkovitých krystalů (obr. 23). Někdy jsou jehličky na plochách chabazitových krystalů vyvinuty samostatně a mají různou délku. Na epitaxně porostlé chabazity často nasedají dokonale čiré a skelně lesklé krystaly jeho mladší generace, případně kapky a náteky čirého opálu.

Phillipsit tvoři v dutinách obvyklé bezbarvé, krátce sloupečkovité, dokonale ukončené (často oboustranně) krystaly o délce 1 až $3 \mathrm{~mm}$. Krystaly mají někdy tabulkovitý charakter, někdy phillipsity vytvářejí i kř́žová dvojčata. Běžné jsou jeho polokulovité a snopkovité agregáty složené z dlouze sloupečkovitých krystalů (obr. 24). Velice neobvyklou formou phillipsitu na lokalitě jsou jeho jednotlivě vyvinuté bělavé pseudohexagonální výrazně jemně korodované krystaly o rozměrech 0.5 až $1 \mathrm{~mm}$. Tyto krystaly mají vzhled sendviče (obr. 25). Lamelární koroze je někdy vidět i na ukončení jednotlivých sloupečkovitých

Tabulka 16 Rentgenová prášková data chabazitu-K ze Stráně

\begin{tabular}{cccccccccccccccccc}
\hline$h$ & $k$ & $l$ & $d_{o b s}$ & $l_{o b s}$ & $d_{c a l c}$ & $h$ & $k$ & $l$ & $d_{o b s}$ & $l_{o b s}$ & $d_{c a l c}$ & $h$ & $k$ & $l$ & $d_{o b s}$ & $l_{\text {obs }}$ & $d_{c a l c}$ \\
\hline 1 & 0 & 1 & 9.330 & 100 & 9.359 & 2 & 2 & 3 & 2.829 & 3 & 2.843 & 6 & 1 & 2 & 1.7700 & $<1$ & 1.7721 \\
1 & 1 & 0 & 6.890 & 9 & 6.904 & 0 & 4 & 2 & 2.769 & 2 & 2.778 & 4 & 4 & 0 & 1.7230 & 17 & 1.7259 \\
0 & 1 & 2 & 6.319 & 4 & 6.325 & 2 & 0 & 5 & 2.694 & 1 & 2.687 & 3 & 3 & 6 & 1.6940 & $<1$ & 1.6951 \\
0 & 2 & 1 & 5.537 & 25 & 5.556 & 4 & 1 & 0 & 2.604 & 5 & 2.609 & 3 & 2 & 7 & 1.6900 & $<1$ & 1.6914 \\
0 & 0 & 3 & 4.967 & 11 & 5.013 & 1 & 3 & 4 & 2.4869 & 3 & 2.4871 & 6 & 2 & 1 & 1.6539 & $<1$ & 1.6482 \\
2 & 0 & 2 & 4.674 & 2 & 4.680 & 1 & 1 & 6 & 2.3557 & $<1$ & 2.3560 & 3 & 4 & 5 & 1.6461 & 1 & 1.6455 \\
2 & 1 & 1 & 4.316 & 77 & 4.328 & 4 & 0 & 4 & 2.3357 & 1 & 2.3399 & 3 & 1 & 8 & 1.6353 & 1 & 1.6354 \\
1 & 1 & 3 & 4.050 & $<1$ & 4.056 & 3 & 3 & 0 & 2.3068 & $<1$ & 2.3012 & 2 & 3 & 8 & 1.5532 & 1 & 1.5507 \\
3 & 0 & 0 & 3.978 & 4 & 3.986 & 5 & 0 & 2 & 2.2731 & 1 & 2.2790 & 5 & 1 & 7 & 1.5210 & 1 & 1.5189 \\
1 & 2 & 2 & 3.855 & 19 & 3.874 & 4 & 2 & 2 & 2.1584 & $<1$ & 2.1641 & 7 & 1 & 3 & 1.5124 & 1 & 1.5102 \\
2 & 2 & 0 & 3.443 & 60 & 3.452 & 3 & 0 & 6 & 2.1210 & 1 & 2.1218 & 5 & 3 & 5 & 1.4849 & 2 & 1.4854 \\
1 & 3 & 1 & 3.228 & 7 & 3.239 & 3 & 3 & 3 & 2.0848 & 2 & 2.0813 & 8 & 0 & 2 & 1.4662 & $<1$ & 1.4660 \\
0 & 2 & 4 & 3.162 & 4 & 3.183 & 1 & 5 & 2 & 2.0679 & 2 & 2.0650 & 1 & 5 & 8 & 1.4157 & 1 & 1.4145 \\
3 & 0 & 3 & 3.132 & 23 & 3.120 & 3 & 4 & 2 & 1.9059 & $<1$ & 1.9018 & 8 & 1 & 1 & 1.3943 & 1 & 1.3935 \\
4 & 0 & 1 & 2.930 & 45 & 2.932 & 0 & 1 & 8 & 1.8610 & 2 & 1.8517 & 3 & 4 & 8 & 1.3586 & 1 & 1.3586 \\
2 & 1 & 4 & 2.886 & 11 & 2.890 & 1 & 3 & 7 & 1.8022 & 2 & 1.8031 & & & & & \\
\hline
\end{tabular}

Tabulka 17 Chemické složení chabazitu-K ze Stráně (hm. \%)

\begin{tabular}{lrrrrrr}
\hline & mean & 1 & 2 & 3 & 4 & 5 \\
\hline $\mathrm{SiO}_{2}$ & 55.76 & 55.38 & 55.74 & 54.96 & 56.10 & 56.63 \\
$\mathrm{Al}_{2} \mathrm{O}_{3}$ & 15.13 & 16.85 & 13.08 & 14.68 & 15.49 & 15.57 \\
$\mathrm{MgO}$ & 2.92 & 1.70 & 1.68 & 3.30 & 3.79 & 4.14 \\
$\mathrm{CaO}$ & 2.94 & 5.16 & 3.55 & 2.15 & 2.01 & 1.81 \\
$\mathrm{~K}{ }_{2} \mathrm{O}$ & 5.18 & 5.32 & 3.47 & 5.03 & 7.08 & 4.99 \\
$\mathrm{Na}_{2} \mathrm{O}$ & 0.30 & 0.18 & 0.35 & 0.45 & 0.33 & 0.17 \\
$\mathrm{H}_{2} \mathrm{O}$ & 22.39 & 22.82 & 21.51 & 21.99 & 22.82 & 22.83 \\
\hline $\mathrm{Total}^{4+}$ & 104.62 & 107.41 & 99.38 & 102.56 & 107.62 & 106.14 \\
\hline $\mathrm{Si}^{4+}$ & 8.959 & 8.733 & 9.324 & 8.989 & 8.845 & 8.926 \\
$\mathrm{Al}^{3+}$ & 2.865 & 3.132 & 2.579 & 2.830 & 2.878 & 2.892 \\
$\mathrm{Mg}^{2+}$ & 0.699 & 0.400 & 0.419 & 0.805 & 0.890 & 0.973 \\
$\mathrm{Ca}^{2+}$ & 0.506 & 0.872 & 0.636 & 0.376 & 0.339 & 0.306 \\
$\mathrm{~K}^{+}$ & 1.062 & 1.071 & 0.740 & 1.049 & 1.425 & 1.004 \\
$\mathrm{Na}^{+}$ & 0.093 & 0.055 & 0.113 & 0.143 & 0.100 & 0.051 \\
\hline$\Sigma \mathrm{Mg}+\mathrm{Ca}+\mathrm{K}+\mathrm{Na}$ & 2.360 & 2.343 & 1.908 & 2.373 & 2.754 & 2.334 \\
\hline $\mathrm{H}_{2} \mathrm{O}$ & 12 & 12 & 12 & 12 & 12 & 12 \\
$\mathrm{~T}_{\mathrm{Si}}$ & 0.76 & 0.73 & 0.78 & 0.76 & 0.75 & 0.76 \\
\hline $\mathrm{Empin}$
\end{tabular}

Empirický vzorec byl přepočten na bázi 24 kyslíků. $\mathrm{H}_{2} \mathrm{O}$ bylo dopočítáno na základě teoretického obsahu $12 \mathrm{H}_{2} \mathrm{O}$. 
krystalů v polokulovitých agregátech (obr. 26). Vzhledem $\mathrm{k}$ tomu, že je tato dílčí lokalita úzce spjata s lokalitou Klučky - Stráň, nebyly popisované vzorky samostatně kvantitativně analyzovány.

\section{Lokalita Trojmezí}

Tato lokalita se nachází ve východní části hřbetu v mělkém sedle, cca 500 m východně od vrcholu Klučky, kde stojí starý trojhranný patník s letopočtem 1831 (GPS:

Tabulka 18 Rentgenová prášková data phillipsitu ze Stráně

\begin{tabular}{|c|c|c|c|c|c|c|c|c|c|c|c|c|c|c|c|c|c|}
\hline$h$ & $k$ & I & $d_{o b s}$ & $I_{o b s}$ & $d_{\text {calc }}$ & $h$ & $k$ & T & $d_{o b s}$ & $I_{o b s}$ & $d_{\text {calc }}$ & $h$ & $k$ & 1 & $d_{o b s}$ & $I_{o b s}$ & $d_{\text {calc }}$ \\
\hline-1 & 0 & 1 & 8.160 & 6 & 8.181 & 2 & 4 & 0 & 2.688 & 14 & 2.687 & -2 & 7 & 3 & 1.6738 & 1 & 1.6737 \\
\hline-1 & 1 & 1 & 7.104 & 19 & 7.103 & -3 & 1 & 3 & 2.680 & 7 & 2.679 & 1 & 8 & 1 & 1.6517 & 6 & 1.6517 \\
\hline 0 & 1 & 1 & 6.390 & 18 & 6.408 & 3 & 1 & 0 & 2.663 & 3 & 2.664 & -2 & 8 & 2 & 1.6393 & 1 & 1.6394 \\
\hline 1 & 2 & 0 & 5.360 & 40 & 5.374 & 1 & 2 & 2 & 2.5627 & 2 & 2.5668 & 5 & 1 & 0 & 1.6170 & $<1$ & 1.6166 \\
\hline 0 & 2 & 1 & 5.045 & 31 & 5.064 & 3 & 2 & 0 & 2.5400 & 1 & 2.5359 & -6 & 0 & 2 & 1.6101 & $<1$ & 1.6092 \\
\hline-2 & 0 & 1 & 4.955 & 19 & 4.961 & -4 & 0 & 2 & 2.4821 & 14 & 2.4804 & -6 & 1 & 2 & 1.5979 & 3 & 1.5991 \\
\hline-2 & 1 & 1 & 4.678 & 1 & 4.687 & -1 & 3 & 3 & 2.3879 & 4 & 2.3881 & 5 & 2 & 0 & 1.5876 & $<1$ & 1.5866 \\
\hline-1 & 0 & 2 & 4.309 & 3 & 4.315 & -4 & 0 & 1 & 2.3363 & 3 & 2.3397 & 1 & 0 & 4 & 1.5713 & $<1$ & 1.5710 \\
\hline 1 & 0 & 1 & 4.294 & 5 & 4.295 & -4 & 1 & 1 & 2.3084 & 1 & 2.3091 & -6 & 3 & 3 & 1.5627 & $<1$ & 1.5624 \\
\hline-1 & 3 & 1 & 4.124 & 47 & 4.122 & 2 & 4 & 1 & 2.2521 & 1 & 2.2515 & 1 & 2 & 4 & 1.5351 & 2 & 1.5345 \\
\hline 1 & 1 & 1 & 4.108 & 53 & 4.114 & -4 & 2 & 3 & 2.2294 & 1 & 2.2313 & -5 & 6 & 2 & 1.5167 & $<1$ & 1.5163 \\
\hline-2 & 2 & 1 & 4.080 & 5 & 4.077 & -4 & 3 & 2 & 2.2016 & $<1$ & 2.2008 & -3 & 8 & 3 & 1.4957 & $<1$ & 1.4960 \\
\hline-2 & 1 & 2 & 3.945 & 2 & 3.933 & -3 & 4 & 3 & 2.1660 & $<1$ & 2.1690 & 1 & 9 & 1 & 1.4920 & $<1$ & 1.4916 \\
\hline-1 & 2 & 2 & 3.691 & 3 & 3.695 & -2 & 0 & 4 & 2.1579 & 1 & 2.1573 & 3 & 5 & 2 & 1.4847 & 2 & 1.4846 \\
\hline 1 & 2 & 1 & 3.674 & 2 & 3.683 & -2 & 2 & 4 & 2.0650 & 1 & 2.0656 & -4 & 1 & 6 & 1.4489 & 1 & 1.4490 \\
\hline 2 & 2 & 0 & 3.534 & 2 & 3.536 & 4 & 0 & 0 & 2.0348 & $<1$ & 2.0338 & -6 & 3 & 5 & 1.4361 & 1 & 1.4352 \\
\hline 0 & 1 & 2 & 3.479 & 1 & 3.476 & -3 & 5 & 3 & 1.9740 & 1 & 1.9746 & -4 & 2 & 6 & 1.4272 & 1 & 1.4272 \\
\hline-3 & 0 & 1 & 3.219 & 14 & 3.218 & -4 & 4 & 3 & 1.9634 & 2 & 1.9634 & 3 & 1 & 3 & 1.4242 & $<1$ & 1.4245 \\
\hline 1 & 3 & 1 & 3.194 & 100 & 3.192 & -5 & 2 & 2 & 1.8936 & 1 & 1.8940 & 5 & 5 & 0 & 1.4149 & $<1$ & 1.4146 \\
\hline-3 & 1 & 2 & 3.145 & 28 & 3.148 & -2 & 7 & 2 & 1.8290 & 4 & 1.8291 & 3 & 6 & 2 & 1.4044 & 1 & 1.4039 \\
\hline-3 & 1 & 1 & 3.137 & 35 & 3.140 & -4 & 5 & 1 & 1.8125 & $<1$ & 1.8117 & -7 & 2 & 4 & 1.3849 & $<1$ & 1.3847 \\
\hline-3 & 2 & 2 & 2.937 & 4 & 2.942 & 0 & 8 & 0 & 1.7901 & 3 & 1.7894 & -3 & 8 & 4 & 1.3810 & $<1$ & 1.3812 \\
\hline-3 & 2 & 1 & 2.933 & 8 & 2.935 & -5 & 2 & 4 & 1.7794 & 11 & 1.7788 & -1 & 5 & 5 & 1.3796 & $<1$ & 1.3792 \\
\hline 2 & 0 & 1 & 2.893 & 1 & 2.897 & -5 & 2 & 1 & 1.7711 & 2 & 1.7718 & -2 & 1 & 6 & 1.3730 & $<1$ & 1.3728 \\
\hline-1 & 4 & 2 & 2.753 & 7 & 2.755 & -3 & 5 & 4 & 1.7302 & $<1$ & 1.7307 & -5 & 3 & 6 & 1.3694 & 1 & 1.3691 \\
\hline-1 & 1 & 3 & 2.706 & 13 & 2.709 & -5 & 4 & 2 & 1.7211 & 1 & 1.7218 & -7 & 3 & 4 & 1.3530 & 1 & 1.3534 \\
\hline 1 & 1 & 2 & 2.701 & 16 & 2.700 & -5 & 3 & 4 & 1.7145 & 1 & 1.7139 & -5 & 6 & 5 & 1.3495 & $<1$ & 1.3493 \\
\hline-2 & 4 & 2 & 2.693 & 17 & 2.693 & -2 & 8 & 4 & 1.6831 & $<1$ & 1.6832 & & & & & & \\
\hline
\end{tabular}

Tabulka 19 Chemické složení phillipsitu ze Stráně (hm. \%)

\begin{tabular}{|c|c|c|c|c|c|}
\hline & mean & 1 & 2 & 3 & 4 \\
\hline$\overline{\mathrm{SiO}_{2}}$ & 51.03 & 49.98 & 48.91 & 51.51 & 53.70 \\
\hline $\mathrm{Al}_{2} \mathrm{O}_{3}$ & 20.39 & 20.09 & 20.08 & 20.50 & 20.88 \\
\hline $\mathrm{CaO}$ & 7.10 & 6.81 & 7.02 & 7.23 & 7.33 \\
\hline $\mathrm{SrO}$ & 0.19 & 0.32 & 0.11 & 0.10 & 0.21 \\
\hline $\mathrm{BaO}$ & 0.92 & 1.70 & 0.66 & 0.66 & 0.65 \\
\hline $\mathrm{K}_{2} \mathrm{O}$ & 6.57 & 6.26 & 8.98 & 5.59 & 5.44 \\
\hline $\mathrm{Na}_{2} \mathrm{O}$ & 0.51 & 0.43 & 0.19 & 0.73 & 0.69 \\
\hline $\mathrm{H}_{2} \mathrm{O}$ & 16.96 & 16.64 & 16.54 & 17.05 & 17.62 \\
\hline total & 103.67 & 102.23 & 102.68 & 103.37 & 107.21 \\
\hline$\overline{\mathrm{Si}^{4+}}$ & 10.823 & 10.804 & 10.641 & 10.872 & 10.967 \\
\hline $\mathrm{Al}^{3+}$ & 5.095 & 5.118 & 5.148 & 5.101 & 5.027 \\
\hline $\mathrm{Ca}^{2+}$ & 1.613 & 1.577 & 1.637 & 1.635 & 1.604 \\
\hline $\mathrm{Sr}^{2+}$ & 0.023 & 0.040 & 0.014 & 0.013 & 0.025 \\
\hline $\mathrm{Ba}^{2+}$ & 0.076 & 0.144 & 0.056 & 0.055 & 0.052 \\
\hline $\mathrm{K}^{+}$ & 1.777 & 1.728 & 2.492 & 1.504 & 1.416 \\
\hline $\mathrm{Na}^{+}$ & 0.209 & 0.179 & 0.081 & 0.299 & 0.272 \\
\hline$\Sigma \mathrm{Ca}+\mathrm{Sr}+\mathrm{Ba}+\mathrm{Na}+\mathrm{K}$ & 3.698 & 3.668 & 4.280 & 3.506 & 3.369 \\
\hline $\mathrm{H}_{2} \mathrm{O}$ & 12 & 12 & 12 & 12 & 12 \\
\hline $\mathrm{T}_{\mathrm{Si}}$ & 0.68 & 0.68 & 0.67 & 0.68 & 0.69 \\
\hline
\end{tabular}


5046“49.09“ N; 14³0‘59.07“ E). Výskyt je tvořen nevýrazným výchozem rozpadajícího se vulkanitu (obr. 27), ve kterém jsou drobné dutiny se zeolity a xenokrysty olivínu a tmavě zeleného pyroxenu. Hornina má slabě nahnědle tmavošedou až černošedou barvu. Ve velmi jemnozrnné, pouhým okem nerozlišitelné horninové hmotě se v barevném kontrastu objevují velmi četné bílé zaoblené a mírně protáhlé dutiny o rozměrech 3 až $8 \mathrm{~mm}$, většinově zaplněné druhotnou bílou minerální výplní. Druhou, podstatně méně četnou, ale nepřehlédnutelnou makroskopickou pozoruhodností horniny jsou krystalové xenokrysty světle zelené barvy, patřící olivínu. Dosahují délky až $10 \mathrm{~mm}$. Pokud jsou drobnějších rozměrů (2 až $3 \mathrm{~mm}$ ) ztrácejí místy svou svěží zelenou barvu, která alteračně (iddingsitizací) přechází na rudohnědou. Stavba horniny je všesměrná, nejeví znaky paralelního (fluidálního) uspořádání. $\mathrm{Na}$ základě mikroskopického studia provedeného výbrusu je možné konstatovat, že je hornina, s vynecháním dutin a jejich sekundární výplně, tvořena hrubě krystalovou fází a většinově jemnozrnnou základní hmotou. V hrubé krystalové fázi se objevují vyrostlice klinopyroxenu, zpravidla automorfně omezené. Častější a nápadnější jsou však krystaly olivínu. Z tvarového hlediska je na nich pozoruhodné, že postrádají automorfní omezení, ale vyznačuji se tvarem, který by bylo možno nejspíš označit jako úlomkovitě rozlámaný. $Z$ něho Ize usuzovat, že nejde o vyrostlice, ale o xenokrysty. Je to jev, který mezi bazaltoidy Lužických hor a Českého středohoří je málokdy tak výrazně vyvinutý, jako na této lokalitě. Základní hmotě dominují dva minerály: plagioklas a klinopyroxen. Plagioklas tvoří drobné automorfní lišty o délce do $0.05 \mathrm{~mm}$. Jejich bazicita odpovídá kyselému labradoritu. Místy se na nich projevuje nevýrazné subparalelní uspořádání. Pyroxen základní hmoty je zčásti omezen xenomorfně $v$ podobě izometrických zrn, zčásti $v$ podobě krátkých hypautomorfních sloupečků - obojí o rozměrech kolem 0.01 $\mathrm{mm}$. V množství výrazně menším než v případě plagioklasu vystupuje jako další světlá součástka nefelín, ve stavu silné přeměny na analcim. Tvoří výplňkovou xenomorfní mesostazi. Minerální asociaci doplňují v množství do 10 \% izometrická zrna magnetitu, rozměrově značně kolísající do výjimečné maximální hodnoty $0.1 \mathrm{~mm}$. Přítomnost nepatrného množství mikrolitů apatitu je pravděpodobná. Struktura horniny je porfyrická s mikrokrystalickou strukturou základní hmoty, textura je dutinatě mandlovcovitá. V petrografickém systému Ize horninu označit jako nefelinicko-analcimický bazanit. Za její specifikum Ize kromě hojného výskytu zeolitů označit výskyt olivínových xenokrystů.

Drobné členité dutiny $v$ bazanitu jsou často povlečeny šedivou krustou jílového nerostu. Ze zeolitů v nich byly určeny chaba-

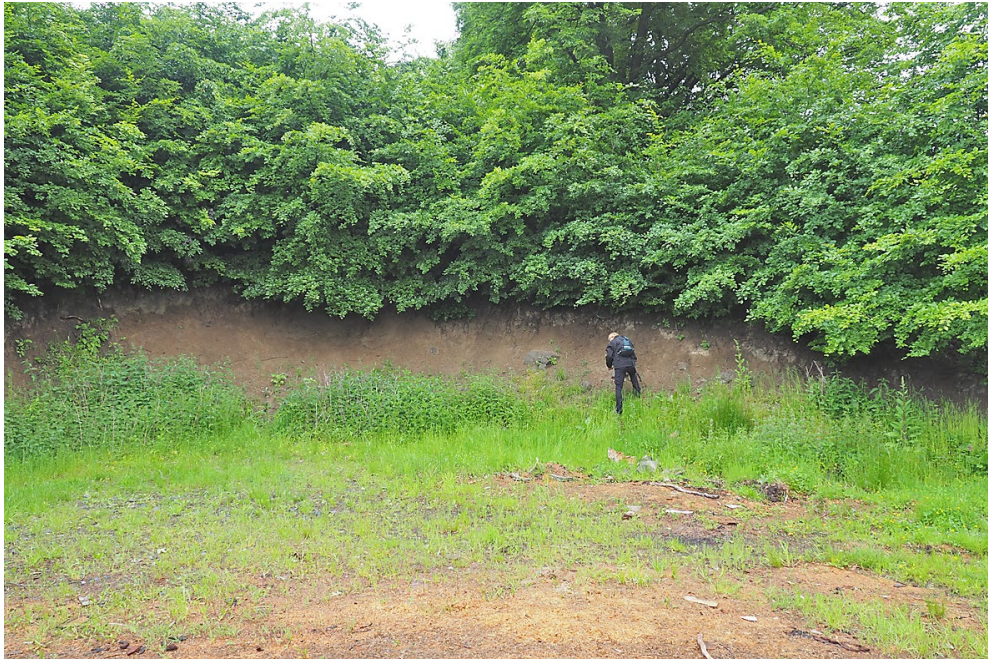

Obr. 21 Skalní odkryv na lokalitě Klučky - Parkoviště, foto P. Pauliš, 2020.

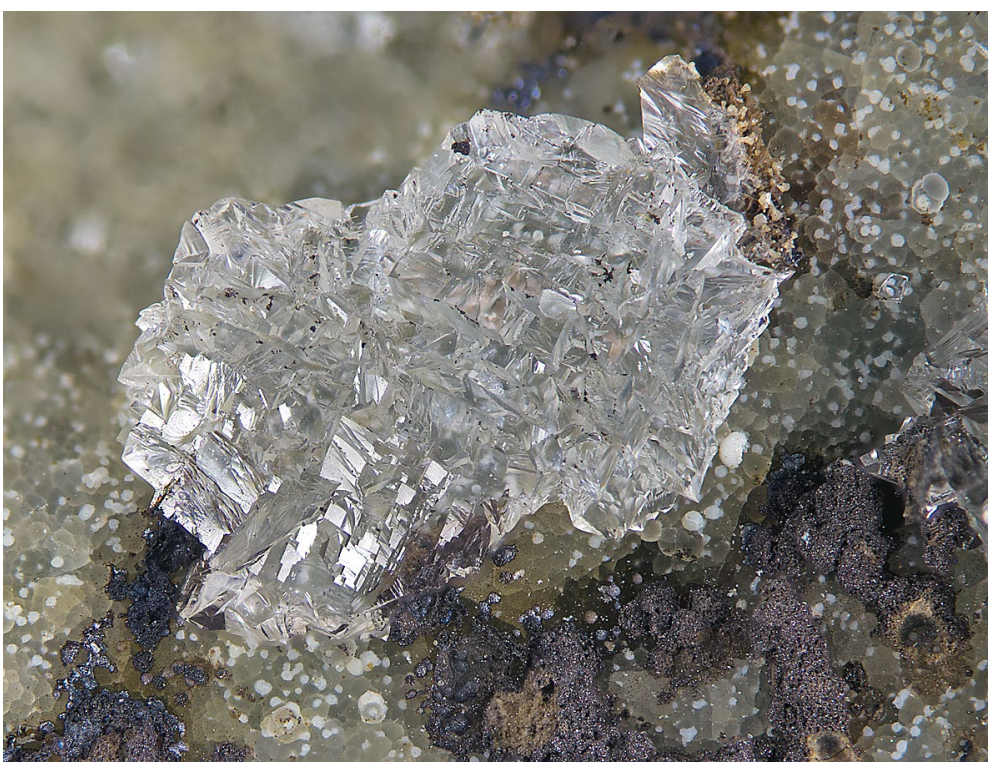

Obr. 22 Neobvyklé kulovité agregáty chabazitu tvořené fakolitovými srostlicemi z lokality Klučky - Parkoviště; šířka záběru $3 \mathrm{~mm}$, foto P. Fuchs.

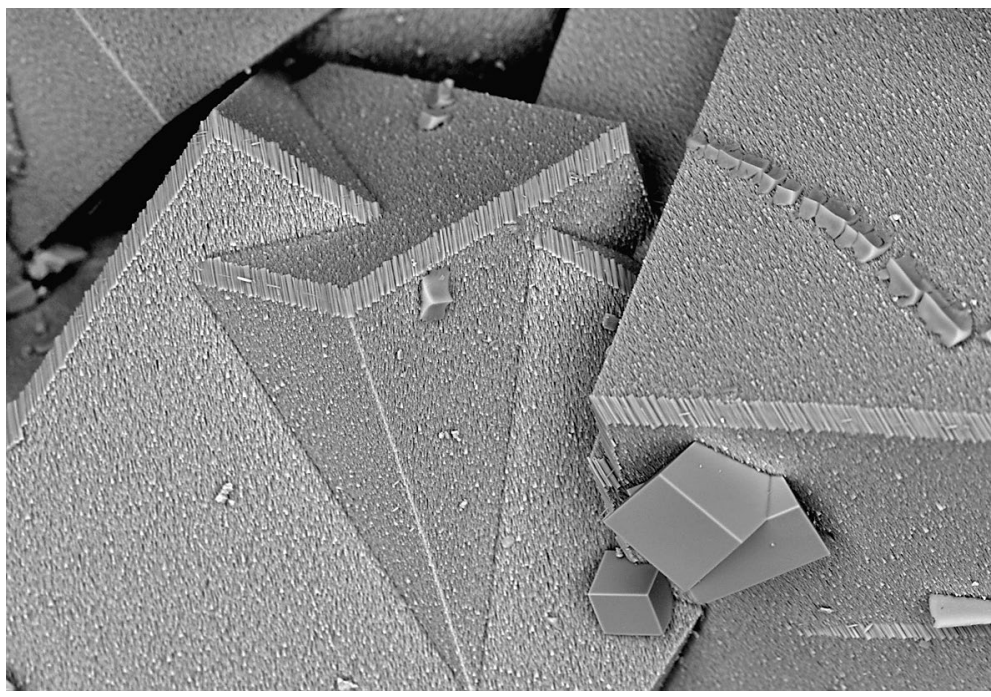

Obr. 23 Detailní záběr nárůstů offretitu na chabazit s dalším nárůstem chabazitu druhé generace z lokality Klučky - Parkoviště; šířka záběru $0.5 \mathrm{~mm}$, BSE foto B. Ekrt. 


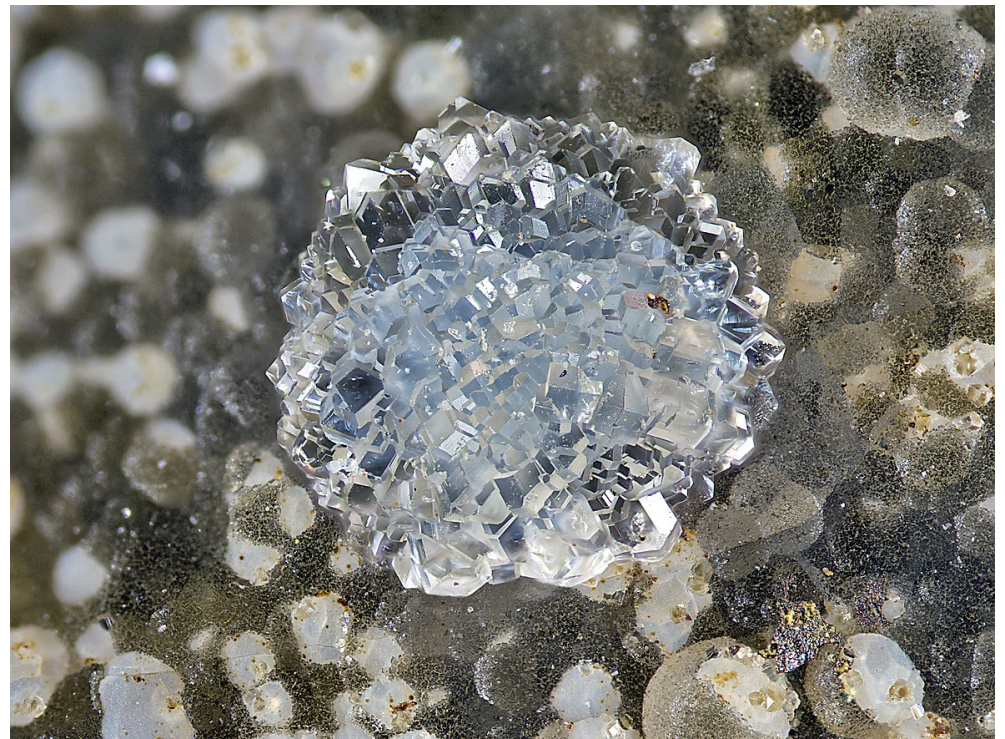

Obr. 24 Agregát phillipsitu nasedající na offretit z lokality Klučky - Parkoviště; šiřka záběru $2 \mathrm{~mm}$, foto $P$. Fuchs.

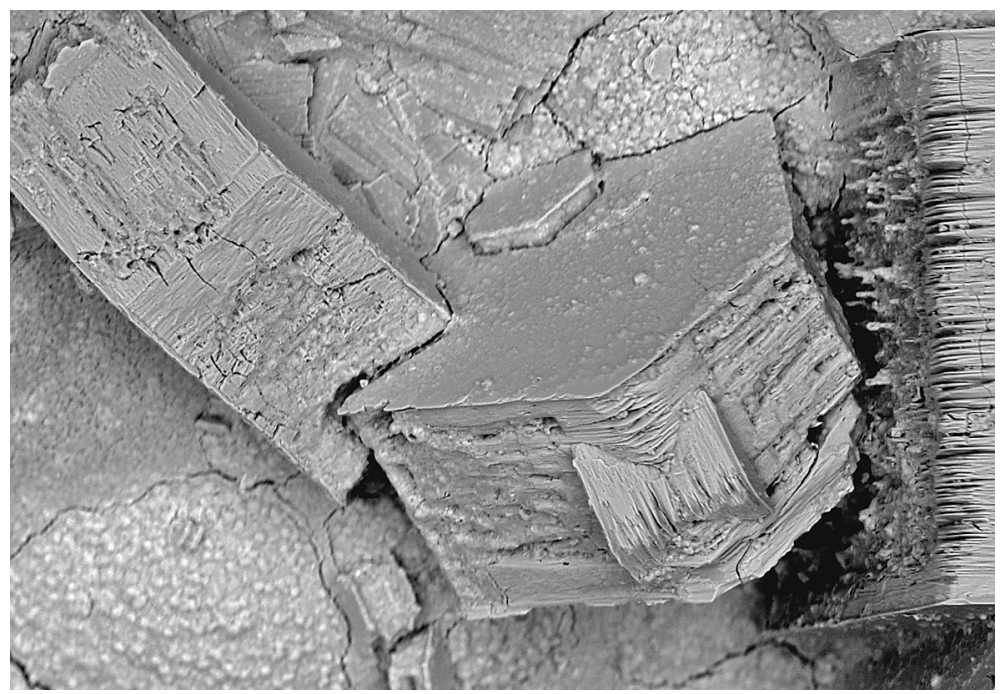

Obr. 25 Detail koroze krystalu phillipsitu z lokality Klučky - Parkoviště; šiřka záběru $0.5 \mathrm{~mm}$, BSE foto B. Ekrt.

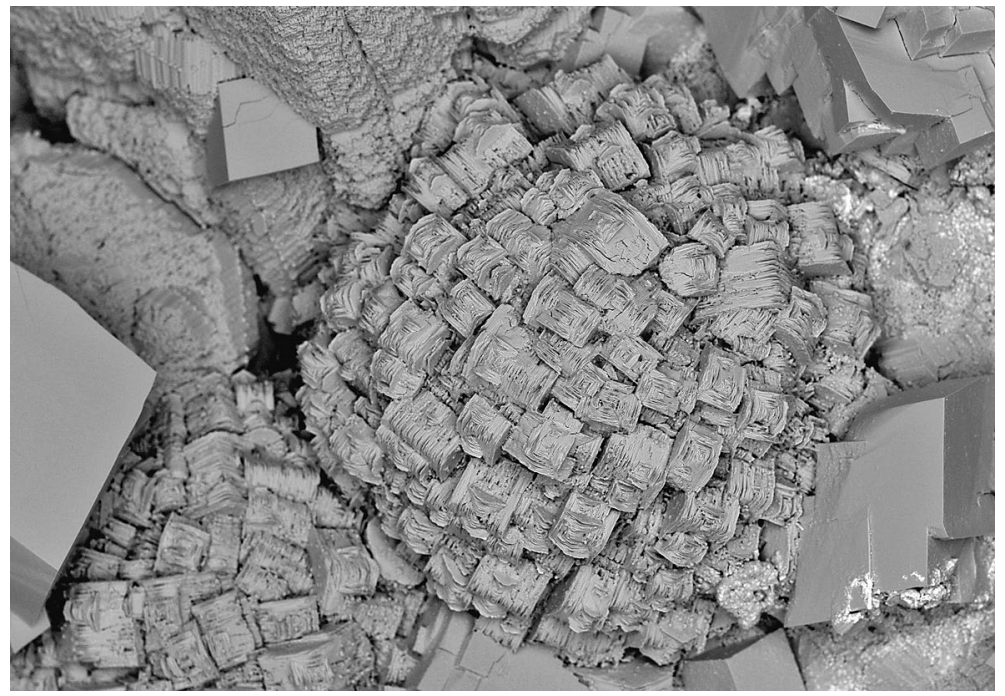

Obr. 26 Agregát phillipsitu s patrnou korozí z lokality Klučky - Parkoviště; šírka záběru $2 \mathrm{~mm}$, BSE foto B. Ekrt. zit, phillipsit a offretit. Vzhledem k tomu, že zjištěné vzorky odpovídají předchozím lokalitám, nebyly samostatně kvantitativně analyzovány. Chabazit vytváří čiré klence dosahující velikostí 1 až $2 \mathrm{~mm}$, phillipsit bezbarvé sloupečky a polokulovité agregáty o průměrech 1 až $2 \mathrm{~mm}$. Offretit $v$ charakteristických šestibokých jehličkách ukončených bází, délky jen zlomků mm, obvykle pokrývá dutiny v podobě souvislé bělavé krusty; vzácnější jsou jeho bezbarvé až $1 \mathrm{~mm}$ dlouhé krystaly jednotlivě narůstající na stěny dutin. Vytváří i snopečkové a polokulovité agregáty prorůstající se ve shlucích na ploše až $0.5 \mathrm{~cm}^{2}$. Zajímavé jsou i xenokrysty olivínu a pyroxenu ve vulkanických horninách. Olivíny jsou hojné, běžně dosahují velikosti kolem $1 \mathrm{~cm}$, vzácněji až $2 \mathrm{~cm}$, jsou výrazně tmavě zelené, většinově čerstvé a hodně rozpraskané. Tmavě zelený pyroxen (pravděpodobně diopsid) je mnohem vzácnější, jeho vyrostlice dosahují velikosti do $2 \mathrm{~cm}$. Jeho barva má trochu jiný odstín než olivín i odlišné rozpraskání. Potvrzen byl, stejně jako olivín, rentgenovou práškovou difrakcí.

\section{Další výskyty zeolitové mineralizace}

Podružné zeolitové mineralizace byly zjištěny na dalších několika místech. $V$ místě zvaném U Obrázku byly v deskovitě odlučném bazaltu zjištěny phillipsit a zeolit natrolitové rady. Dutiny jsou řídké a dosahují velikosti do $1 \mathrm{~cm}$. V zaniklém kamenolomu u vrcholové kóty Klučků byly nalezeny zašlé dutiny až 2 $\mathrm{cm}$ velké s analcimem. Dutiny velikosti do 5 $\mathrm{cm}$ se zeolitem natrolitové řady byly nalezeny ve výchozu a agrárních hrázkách sv. od kóty $633 \mathrm{~m} \mathrm{n}$. m. Jde však o navětralé vzorky. Perspektivní místem nálezů zeolitů se zdá být kamenolom u osady Klučky. Byla zde zjištěna ovšem jen nevýrazná zeolitová mineralizace. Až $2 \mathrm{~cm}$ velké dutiny obsahují zeolity morfologicky odpovídající natrolitu, thomsonitu a phillipsitu. Bohatší je jen výskyt chabazitu $s$ krystaly o velikosti do $2 \mathrm{~mm} v$ trhlinách horniny brekciovitého charakteru.

\section{Závěr}

$V$ zalesněném, asi $3 \mathrm{~km}$ dlouhém vulkanickém hřbetu Klučky, se stejnojmennou kótou 642 m n. m., sz. od Nového Boru, $v$ Lužických horách, byly zjištěny čtyři nové výskyty zeolitů. Vedle phillipsitu a chabazitu je na všech popsaných výskytech hojný offretit, který se vyznačuje neobyčejně velkou morfologickou variabilitou. Podobná situace byla zjištěna na nedalekých lokalitách $U$ poustevny a na Zaječím vrchu u Nového Boru (Pauliš et al. 2019). Nejzajímavějším je však nález poměrně vzácného zeolitu faujasitu-Na na lokalitě Wachstein, pro který je tato lokalita jeho prvním ověřeným výskytem v ČR. Faujasit-Na tu tvoří charakteristické oktaedrické krystaly o velikosti do $0.3 \mathrm{~mm}$, př́ipadně dvojčata podle spinelového zákona. 
Obr. 27 Skalní výchoz na lokalitě Trojmezí, foto L. Hrůzek, 2020.

\section{Poděkování}

Milou povinností autorů je poděkovat za poskytnutí fotografií B. Burešovi z Prahy, P. Fuchsovi z Teplic, B. Ekrtovi z Prahy a V. Betzovi z Taunussteinu. Recenzentům Jiř́mu Tomanovi (Brno) a Martinu Števkovi (Bratislava) za kritické poznámky a doporučení, která vedla ke zkvalitnění rukopisu. Předložená práce vznikla za finanční podpory Ministerstva kultury ČR v rámci institucionálního financování dlouhodobého koncepčního rozvoje výzkumné organizace Národní muzeum (DKRVO 2019-2023/1.I.b, 00023272).

\section{Literatura}

BETZ V (2019) Zeolithe und andere Mineralien aus den Vulkaniten des Vogelsberges (Hessen) und ihre Fundorte. Aufschluss 4: 208-260

Coombs DS, Alberti A, Armbruster t, Artioli G, Colella C, Galli E, Grice JD, Liebau F, Mandarino JA, Minato H, Nickel EH, Passaglia E, Peacor DR, Quartieri S, Rinaldi R, Ross M, Sheppard RA, Tillmanns E, Vezzalini G (1997) Recommended nomenclature for zeolite minerals: report of the subcommittee on zeolites of the International Mineralogical Association, commission on new minerals and mineral names. Can Mineral 35: 1571-1606

DAmour AA (1842) Description de la faujasite, nouvelle espèce minerále. Annales des Mines 1: 395-397

Gatta GD, Cappelletti P, Rotiroti N, Slebodnick C, Rinaldi $R$ (2009) New insights into the crystal structure and crystal chemistry of the zeolite phillipsite. Am Mineral 94: 190-199

GotTARDI G, Galli E (1985) Natural zeolites. Springer Verlag

Gualtieri A, Artioli G, Passaglia E, Bigi S, Viani A, Hanson JC (1998) Crystal structure - crystal chemistry relationships in the zeolites erionite and offretite. Am Mineral 83: 590-606

KRATOCHVÍL J (1962) Topografická mineralogie Čech V (O - Ř). Nakladatelství ČSAV, Praha

LAUGIER J, BOCHU B (2011) LMGP-suite of programs for the interpretation of X-ray experiments. http://www.ccp14. ac.uk/tutorial/lmgp, přístup duben 2011

Passaglia E, Artioli G, Gualtieri A (1998) The crystal chemistry of the zeolite erionite and offretite. Am Mineral 83: 577-589

Pauliš P, Svejkovský J, Janeček $O$, Hrůzek L, DVoŘák $Z$, JeBAVÁ I (2013) Offretit kamenolomu Vrbička u Valče v Doupovských horách. Bull mineral-petrolog Odd Nár Muz (Praha) 21(2): 171-178

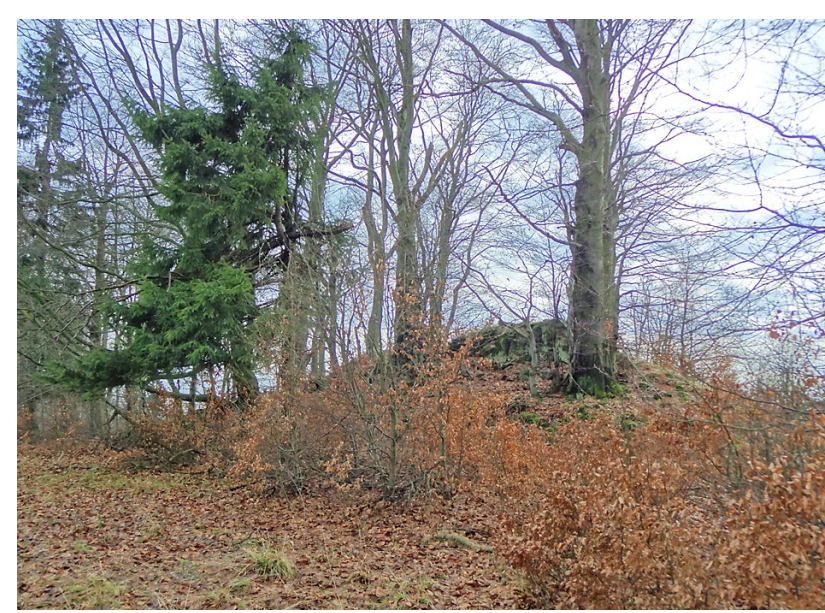

Pauliš P, Hrưzek L, Janeček O, Sejkora J, Malíková R (2014) Cowlesit a doprovodná mineralizace z vrchu Hackenberg u České Kamenice (Česká republika). Bull mineral-petrolog Odd Nár Muz (Praha) 22(2): 248-260

Pauliš P, Hrưzek L, Janeček O, Sejkora J, Maliková R, Pour O, Fediuk F (2015) Tschernichit, garronit-Ca a doprovodná zeolitová mineralizace z Jehly u České Kamenice (Česká republika). Bull mineral-petrolog Odd Nár Muz (Praha) 23(2): 147-170

Pauliš P, Hrưzek L. Janeček O, Sejkora J, Malíková R, FeDIUK F (2016a): Zeolitová mineralizace z Nového Oldřichova u Kamenického Šenova (Česká republika). Bull mineral-petrolog Odd Nár Muz (Praha) 24(1): 100-113

Pauliš P, Hrưzek L, Janeček O, Sejkora J, Malíková R, Pour O, Fediuk F (2016b) Zeolitová mineralizace ze Svoru u Nového Boru (Česká republika). Bull mineral -petrolog Odd Nár Muz (Praha) 24(2): 194-204

Pauliš P, Hrưzek L, Sejkora J, Radoñ M, VRtišKa L, MalíkoVÁ R, FEDIUK F, Pour O (2017a): Zeolitová mineralizace z Lískového vršku u Okřešic u České Lípy (Česká republika). Bull Mineral Petrolog 25(2): 170-181

Pauliš P, Janeček O, Hrưzek L, Sejkora J, Malíková R, FeDIUK F, Pour O (2017b): Nordstrandit a zeolitová mineralizace fonolitu Tachovského vrchu u Doks (Česká republika). Bull Mineral Petrolog 25(1): 69-84

Pauliš P, Hrůzek L, Sejkora J, Adamovič J, Radoñ $M$, VRtIŠKA L, MalíKová R, FediuK F, Pour O (2018a) Zeolitová mineralizace z Klučku u Heřmaniček u České Lípy (Česká republika). Bull Mineral Petrolog 26(1): 43-56

Pauliš P, Zeman P, Zeman V, SEJkora J, Malíková R, VRtiška L, Dolniček Z, Fediuk F, Pour O, Radoñ M (2018b): Zeolitová mineralizace z Heřmanic u České Lípy (Česká republika). Bull Mineral Petrolog 26(2): 123-137

Pauliš P, Hrưzek L, Sejkora J, Dolniček Z, VRtiška L, MaLíková R, Ekrt B, Pour O, Fediuk F, JANeČEk O (2019) Zeolitová mineralizace ze Zaječího vrchu a Poustevny u Nového Boru (Česká republika). Bull Mineral Petro$\log 27(2): 346-370$

Pouchou JL, PICHOIR F (1985) "PAP" ( $\varphi \rho Z)$ procedure for improved quantitative microanalysis. In: Microbeam Analysis (J. T. Armstrong, ed.). San Francisco Press, San Francisco, 104-106

RINALDI R, Smith JV, Jung G (1975) Chemistry and paragenesis of faujasite, phillipsite and offretite from Sasbach, Kaiserstuhl, Germany. N Jb Miner Mh: 433-443

RYCHLỲ R, TSCHERNICH R (1997) Cowlesit, faujasit, boggsit a tschernichit - nové zeolity pro Českou republiku. Přednáška 2. semináře České zeolitové skupiny, Turnov 
RYCHLÝ R, TSCHERNICH R (1998) Cowlesit, faujasit, gobbinsit - nové zeolity pro ČR. Minerál 6(2): 94-95

Senger A (1929) Rhönit-Basalt vom Bildstein bei Parchen. Firgenwald 2: 54-56, Reichenberg

SHRBENÝ O (1963) Geologické a petrografické poměry třetihorních vyvřelin severně od Nového Boru. Sbor geol Věd, Geol 2: 121-138

ScheUmanN KH (1913) Petrographische Untersuchungen an Gesteinen des Polzengebietes in Nordböhmen. Abh der mat phys KI der königl sächs Gesellsch der Wissenschaft 32, 7. Leipzig

TSCHERNICH RW (1992) Zeolites of the world. Geoscience Press, Phoenix

Weisenberger T, Spürgin S (2009) Zeolites in alcaline rocks of the Kaiserstuhl volcanic complex, SW Germany - new microprobe investigation and the relationship of the zeolite mineralogy to the host rock. Geol Belg 12 (1-2): 75-91
WISE WS (1982) New occurence of faujasite in southern Kalifornia. Am Mineral 67: 794-798

WuRm F (1916) Beiträge zur Kenntnis der Eruptivgesteine der Böhm. Leipaer Umgebung. Separat-Abdruck aus den Verh der k k geol Reichsanst: 305-313. Wien

Wurm F, Zimmerhackel P (1882) Basalt und Phonolitkuppen in der Umgebung von Böhm. Leipa. Separat-Abdruck des Programmaufsatzes der Communal Oberrealschule zu B. Leipa, Böhm Leipa

Yakubovich OV, Massa W, Gavrilenko PG, Pekov IV (2005) Crystal structure of chabazite. Kristallografiya 50(4): 595-604 